\title{
Meta-analysis of the effect of oral selenium supplementation on milk selenium concentration in cattle
}

\author{
A. Ceballos, ${ }^{\star 1}$ J. Sánchez,† H. Stryhn, ${ }^{*}$ J. B. Montgomery, ${ }^{*}$ H. W. Barkema,‡ and J. J. Wichtel ${ }^{\star}$ \\ ${ }^{*}$ Department of Health Management, Atlantic Veterinary College, University of Prince Edward Island, Charlottetown, Prince Edward Island \\ C1A 4P3, Canada \\ †Canadian Food and Inspection Agency, Charlottetown, Prince Edward Island C1E 1E3, Canada \\ ¥Department of Production Animal Health, Faculty of Veterinary Medicine, University of Calgary, Calgary, Alberta, T2N 4N1, Canada
}

\begin{abstract}
Soils in many regions of the world have a low Se content. Consequently, forages and crops grown on these soils may provide inadequate dietary Se for humans and grazing animals. Selenium supplementation has been used to enhance Se status and milk Se concentration, but results conflict. Milk Se concentration appears to be a useful indicator of animal and herd Se status, and reflects the responsiveness to supplementation. A systematic review and meta-analysis were carried out to summarize all available scientific evidence for the effect of oral Se supplementation on milk Se concentration in cattle. The literature search was based on electronic and nonelectronic databases. Fixed- and random-effects models of meta-analysis were used, and a meta-regression was carried out to evaluate heterogeneity among studies. Random-effects meta-analysis was performed on 42 studies published between 1977 and 2007. Oral Se supplementation resulted in an average increase in milk Se content of 0.16 (95\% confidence interval: $0.117,0.207) \mu \mathrm{mol} / \mathrm{L}$, with a significant heterogeneity among studies. Weak publication bias was evident, but it did not change the average effect. The continent where the study was performed, Se source, Se dose, and the interaction between source and dose explained $71 \%$ of the between-study variance. On average, American cows supplemented with Se yeast (e.g., $6 \mathrm{mg} / \mathrm{h}$ per day) had greater milk Se concentrations (approximately $0.37 \mu \mathrm{mol} / \mathrm{L}$ ) $75 \mathrm{~d}$ after the beginning of supplementation when compared with those supplemented with inorganic forms of Se. This information provides a basis for tailoring daily animal requirements and for enhancing the Se intake of consumers of dairy products.
\end{abstract}

Key words: cattle, milk, selenium, meta-analysis

Received July 11, 2008.

Accepted September 3, 2008.

${ }^{1}$ Corresponding author: aceballos@upei.ca

\section{INTRODUCTION}

Selenium is a naturally occurring solid substance typically defined as nonmetallic that occurs worldwide but is distributed unevenly in soils (Oldfield, 2002). Many regions of the world have soils with low Se content; consequently, feedstuffs grown on these soils may provide inadequate dietary Se for humans and grazing animals. Selenium nutritional requirements for beef and dairy cattle have been set at 0.1 and $0.3 \mathrm{mg} / \mathrm{kg}$ on a DM basis, respectively (NRC, 2000, 2001). Although Se is not an essential nutrient for plant growth, agricultural practices, such as application of inorganic fertilizers, may contribute to further reducing the content of Se in soils and plants (Hartikainen, 2005). The consumption of animal products derived from animals grazing in low-Se areas can influence the Se status of entire human communities, putting humans at risk of overt deficiency (World Health Organization/Food and Agriculture Organization of the United Nations, 2004). This risk has been recognized by some countries, for instance Finland, where Se application to grain crops grown for human consumption is required by law (Hartikainen and Ekholm, 2001).

Milk derived from cattle on pasture contributes to a person's daily intake of Se, because daily consumption of $100 \mathrm{~g}$ of milk will provide at least $10 \%$ of the daily Se requirement for adults (Knowles et al., 2004). Moreover, it is recommended that milk-based formulas used for infants provide at least $10 \mu \mathrm{g}$ of $\mathrm{Se} / \mathrm{d}$ to complement the maternal supply (World Health Organization/Food and Agriculture Organization of the United Nations, 2004), but nonfortified cow's milk-based formulas will often not provide this amount (Carver, 2003). Consequently, tailoring dairy products to meet specific requirements of a population, such as enhanced Se intake, is an attractive concept for the promotion of human health (Knowles et al., 1999, 2004).

Feeding systems to increase milk Se content have been developed (Knowles et al., 1999; Grace et al., 2001; Guyot et al., 2007). Early studies in the 1970s indicated that a relatively small proportion of Se was 
transferred into milk after feeding inorganic forms of Se such as sodium selenite. Supplementation with sodium selenite increased milk Se content when cows were fed rations low in naturally occurring $\mathrm{Se}$, but there was less impact when cows were fed rations greater in naturally occurring Se (Conrad and Moxon, 1979). In fact, many experiments have shown that Se supplementation results in an increase in the Se content of milk, but it does not appear to increase linearly as Se intake increases (Conrad and Moxon, 1979). These authors concluded that Se from natural sources might be transferred more readily to milk, probably because of its greater bioavailability. In addition, it was noted that an increase in Se intake would not produce important increases in milk Se content when cows were fed Se-adequate rations (Aspila, 1991). Further studies have reported different effects of Se supplementation on milk Se concentration, depending on previous and current dietary Se content, source, and route of administration (Aspila, 1991; Malbe et al., 1995; Knowles et al., 1999), but not all attempts to increase milk Se concentration have been successful (Stowe et al., 1988; Gierus et al., 2003). Trials in cattle have shown variable results after using different sources, doses, and routes of administration of Se, describing either nonsignificant effects (Ammerman et al., 1980) or milk Se concentrations increased by as much as 7-fold (Guyot et al., 2007).

The incorporation of Se into the various fractions of milk may vary depending on the source and route of administration of the supplement. Although this may have practical implications for the dairy-processing industry, it has not been adequately examined to date. In addition, many supplementation experiments have been conducted for only short durations, not long enough for milk to reach a steady-state Se concentration after a change of intake. Consequently, there is a need to summarize the response to different sources of supplementary Se and its transfer into milk, to assist in the design of effective supplementation programs to produce dairy products of the best quality for human consumption, and to address the growing market for enriched foods that meet particular health and lifestyle demands. Clear guidelines concerning how Se supplements should be administered to cattle, in particular, to produce Se-fortified milk for human consumption have not been available.

Narrative reviews have indicated a beneficial effect of Se supplementation on milk Se concentration (Conrad and Moxon, 1980; Weiss, 2005). Traditional narrative reviews have been widely used in veterinary literature to collate existing evidence on a particular intervention, but the majority of these do not use either a systematic or a statistical method to identify, assess, and synthesize the information they are gathering. Narrative reviews are subjective and based on the preconceived opinions of the reviewer, and are therefore prone to bias (Sargeant et al., 2006). On the other hand, systematic reviews appraise critically, summarize, and attempt to reconcile all published evidence concerning a particular intervention (Jadad et al., 1997). They minimize systematic and random errors, and may or may not include a quantitative statistical analysis (meta-analysis) of the results of 2 or more studies to produce an average estimate of the treatment effect (Jadad et al., 1998; Sargeant et al., 2006). The objective of this study was to summarize, through a systematic review and metaanalysis, all available scientific evidence related to the effect of oral Se supplementation on milk Se concentration in cattle.

\section{MATERIALS AND METHODS}

\section{Literature Search}

An electronic and nonelectronic literature search was conducted to identify primary studies carried out between January of 1970 and March of 2008. The server of the University of Prince Edward Island was used to cover Agricola (via CSA Illumina), CAB Abstracts (via OvidSP), MEDLINE (via EBSCOhost), PubMed (via the Internet), ScienceDirect, Web of Science, and WorldCat Basic Search. The keyword combinations were (ruminant OR bovine OR cattle OR cow* OR heifer*) AND (selenium OR glutathione peroxidase OR gsh-px OR gpx) AND (experiment* OR trial* OR effect* OR study OR studies OR supplement*) AND (colostrum OR milk OR dairy products*). Primary studies published in English, French, Italian, Portuguese, Spanish, and German were included. There was no restriction to peer-reviewed journals, and the eligible publications included abstracts, conference proceedings, book chapters, and theses. Additionally, the following proceedings were scanned for references: American Dairy Science Association (1970 to 2007) and American Society of Animal Science (1970 to 2007). All references related to milk Se concentration cited in 3 recent review papers (Weiss, 2005; Gierus, 2007; Guyot and Rollin, 2007) were also identified. In addition, different groups of investigators from the National Chung Hsing University (China), Primary Industries Research Victoria (Australia), Ohio State University (United States), Swedish University of Agricultural Sciences (Sweden), Università Cattolica del Sacro Cuore (Italy), and University of Veterinary and Pharmaceutical Sciences (Czech Republic) were contacted by e-mail asking for unpublished studies related to the intervention of interest. Finally, the potential studies were combined with a set of studies recovered online from the trial database of Alltech Inc. (Nicholasville, KY). 
Manuscripts were excluded if the title or abstract indicated that the study pertained to species different from cattle, or pertained to supplementation trials enrolling animals other than first-calving heifers or multiparous cows, or if the milk Se concentration was not evaluated. Additionally, studies were excluded if cows were supplemented with Se sources other than sodium selenite, sodium selenate, or Se yeast, because those forms are the most widely used for oral supplementation in cattle (Weiss, 2005).

\section{Outcome Evaluated and Data Extraction}

The mean difference in milk Se concentration between Se-supplemented and unsupplemented cows was the outcome of interest. The milk Se concentration increased sharply within the first $28 \mathrm{~d}$ of supplementation and decreased rapidly when supplementation was discontinued. Because very few studies extended the supplementation beyond 170 d, only milk Se concentration data between 28 and $170 \mathrm{~d}$ were considered for the meta-analysis.

All results were transformed to micromoles per liter if the paper cited the results using different units. For unit standardization, $78.96 \mathrm{~g} / \mathrm{mol}$ was used for Se molecular weight (Barthelmy, 2005) and, on average, 1,030 $\mathrm{g} / \mathrm{L}$ was used for milk density (Goff, 2008). Clinical trials were included regardless of whether they were conducted in a randomized fashion.

The precision of the estimate was based on its reported standard error (SE) or on an SE calculated from standard deviations (SD) of the treatment and control groups. In studies involving repeated measures on the same cows, estimates of milk Se concentration at different time points were computed, and the variance was adjusted by an inflation factor given by the formula (Dohoo et al., 2003):

$$
\sigma_{y}^{2}=\frac{\sigma_{y}^{2}}{m}[1+(m-1) \rho]
$$

where $\sigma_{y}^{2}$ is the variance at each time point, $m$ is the number of time points, $\rho$ is the intraclass correlation coefficient within cows, and $[1+(m-1) \rho]$ corresponds to the variance inflation factor. To adjust for clustering within cows, different intraclass correlation coefficient values (i.e., 0.90, 0.75, and 0.25) were assumed.

The same value for the SE or SD was used in both groups when the paper reported a common value for the study groups. Computation of a common SD was made by reconstructing the statistical analysis, if the information needed was available. For example, if the paper reported only the mean for milk Se concentration and a $P$-value, possibly in the form $P<0.05$, the SD was reconstructed under the assumption of a normal distribution analysis as follows:

$$
S D=\left(\bar{x}_{2}-\bar{x}_{1}\right) / t_{(\alpha, d f E)} \sqrt{\frac{1}{n_{2}}+\frac{1}{n_{1}}},
$$

where $\bar{x}_{2}-\bar{x}_{1}$ represents the difference between means; $t_{(\alpha, d f E)}$ is the percentile from the reference distribution; and $n$ is the sample size of each group. When an exact calculation of SD was not possible, a SD was imputed as the pooled $\mathrm{SD}\left(\mathrm{SD}_{p}\right)$ from all the other available studies included in the meta-analysis (Furukawa et al., 2006).

In one manuscript, the mean milk Se concentration and its SE were reported on a log scale (Hidiroglou et al., 1987a). Assuming that log-transformed values followed a normal distribution with the SD derived from the SE and sample size, values on the log scale were recalculated by simulation, and then back transformed to calculate the arithmetic mean and its SE.

Additional considerations in the data-extraction process were as follows. If a study contributed more than one set of observations because data were reported separately by parity, by study year, or by Se source or Se dose, data for each set of observations were recorded separately. Other information was recorded, if available, from the selected studies (Table 1). Two independent investigators extracted the information by using a structured data-collection form, and the first author resolved the discrepancies after re-reviewing the paper.

\section{Meta-Analysis}

The effect of Se supplementation on milk Se concentration in cattle was evaluated by carrying out fixedeffects and random-effects meta-analyses. The results reported in this paper correspond to the random-effects meta-analysis, given the observed heterogeneity of the results across the studies. The $Q$ and $I^{2}$ statistics were used to evaluate whether heterogeneity was present in this study (Deeks et al., 2001; Higgins et al., 2003). The random-effects meta-analysis was estimated according to

$$
\begin{gathered}
T_{i}=\theta+u_{i}+\varepsilon_{i}, \text { and } \\
\operatorname{Var}\left(T_{i}\right)=\tau^{2}+v_{i},
\end{gathered}
$$


Table 1. Additional information extracted from selected studies to evaluate the effect of oral Se supplementation on milk Se concentration in cattle

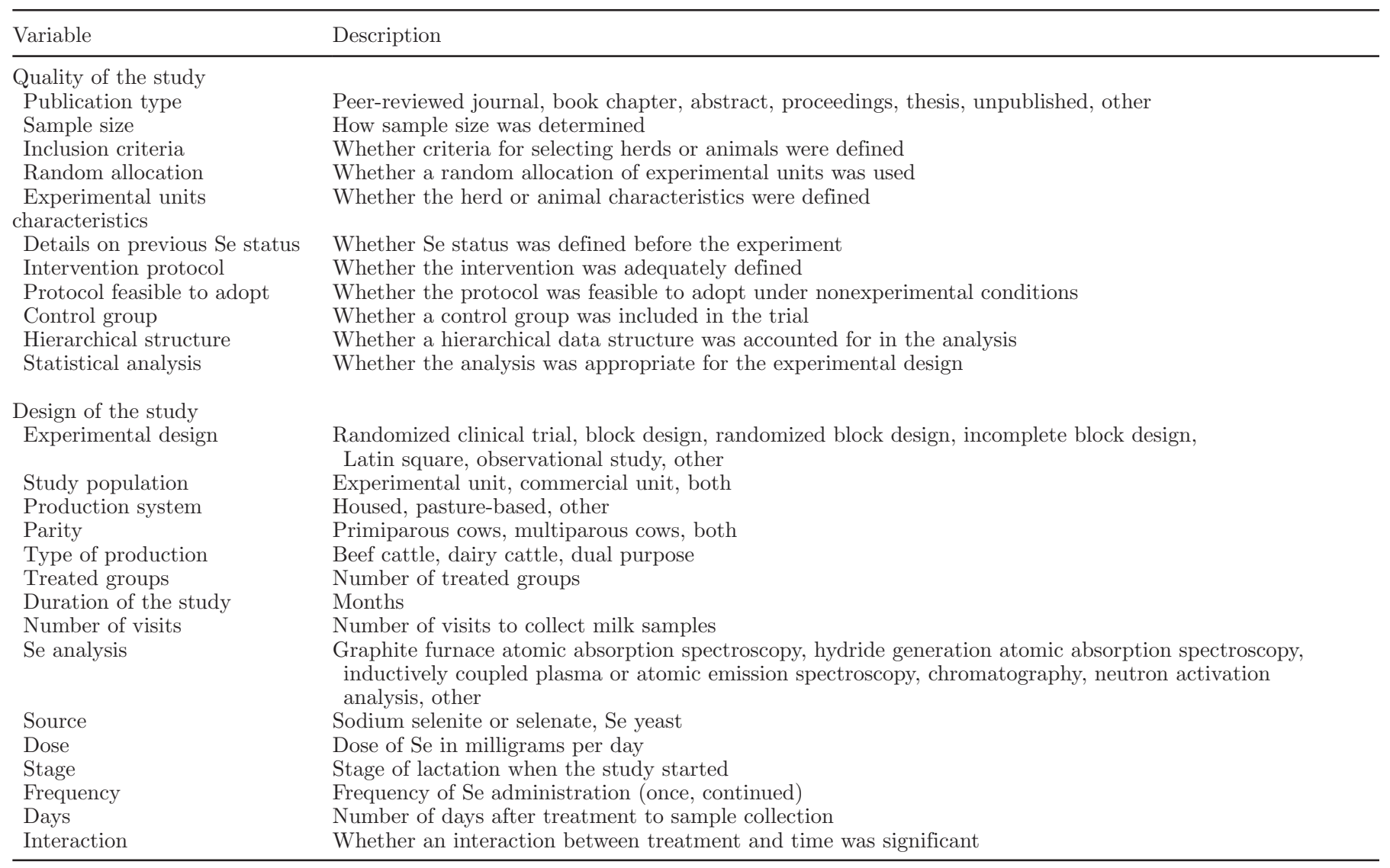

where $T_{i}$ is the effect of the $i$ th study; $\theta$ is the true effect, $u_{i}$ is the random effect of study $i$; and $\varepsilon_{i}$ is the residual error. The variance of $T_{i}$ was computed as the sum of the between-study variance $\left(\tau^{2}\right)$ and the within study variance $\left(v_{i}\right)$ (Sutton et al., 2000). The random-effects meta-analysis was carried out via the method-of-moments estimation (DerSimonian and Laird, 1986). The result of the meta-analysis was presented graphically by using a forest plot. Moreover, the prediction interval for the treatment effect of a new trial was calculated and presented as part of the forest plot (Harris et al., 2008). This interval is a prediction of the range within which the milk Se concentration will lie in a new trial evaluating the effect of oral Se supplementation.

\section{Publication Bias}

Studies showing no effect, not written in English, or containing results unfavorable to the study sponsor might be less likely to be published or included in the analysis than those reporting significant, favorable results. This is known as publication bias (Sterne et al., 2001). Statistical (Begg's and Egger's tests) and graphical methods (funnel plot) were used to evaluate possible publication bias. Additionally, the "trim-andfill" method was used to estimate and correct for an eventual publication bias. Studies having a large SE or low statistical effects (i.e., "small studies") were omitted (trimming) until a funnel plot became symmetrical. Further the "true" center of the plot was reestimated, and the omitted studies were then replaced with their "missing" counterpart studies around the center (Duval and Tweedie, 2000; Sterne et al., 2001). This method evaluates how much the average estimate of treatment effect changes if studies are missing because of publication bias (Duval and Tweedie, 2000).

\section{Meta-Regression}

The meta-regression analysis is a regression-type analysis in which each study is weighted by its precision. It is an extension of the random-effects meta-analysis 
to estimate the extent to which one or more covariates explain heterogeneity in the treatment effects. The meta-regression of the factors related to the quality and design of the study (Table 1) on the factor of interest was performed by using the method-of-moments estimation (Sutton et al., 2000). This method of estimation was preferred for consistency with the other analyses. Other methods of estimation resulted in changes in the between-study variance but had only a minor impact on the regression coefficients.

Unconditional analyses of trial precision, continent where the study was performed, study population, parity, type of production, source of Se and dose of Se, days, stage of lactation, and frequency of administration were evaluated, and unconditionally significant $(P<0.15)$ associated variables were then retained to build a multivariable regression model. Further, the multivariable model was manually reduced by backward selection of the significant variables $(P<0.05)$. Each covariate was evaluated to determine, for each predictor, how much of the between-study variance was accounted for.

\section{Cumulative Meta-Analysis}

Cumulative meta-analysis is the product of performing a new meta-analysis every time a new trial is added to a series of trials. Repeated poolings, instead of a single pooling estimation, are performed as each study is added (Lau et al., 1995). Cumulative meta-analysis was used as an exploratory tool to identify retrospectively whenever the Se supplementation effect first reached statistical significance. Moreover, cumulative meta-analysis was used to correlate the accruing evidence with recommendations made by experts (Egger et al., 2001) and to identify eventual temporal patterns in the trial results (Lau et al., 1995).

\section{Influential Studies}

Studies influencing the summary estimate were identified, generating an influence plot. An influence graph was generated as an SE bar chart, in which summary estimates were computed after sequentially omitting one study at a time (Deeks et al., 2001). Those studies having an undue influence on the estimation of the average effect of treatment were identified.

All analyses were carried out with Stata Statistical Software release 10.0, using the commands metan, metabias, metafunnel, metareg, metacum, and metaninf (StataCorp., College Station, TX). No adjustment for clustering within author was made because of the low number of studies performed by the same author.

\section{RESULTS}

\section{Literature Search}

The search identified 139 potential references containing the keyword combination in either their titles or their abstracts. A total of 23 references could not be recovered (1 narrative review, 4 duplicates of other studies, 3 written in English, and 15 written in a language beyond the scope of the selected languages). From the remaining 116 references, 77 were excluded from the analysis (see Appendix). In 3 manuscripts, the outcome of interest was described, but no data were recorded because supranutritional doses of Se were used. These reports were written in English, and their results are shown in Table 2. Three manuscripts reported the results of 5 studies in which milk Se concentration was evaluated at time points other than between 28 and 170 $\mathrm{d}$ from treatment, and these were excluded from the meta-analysis (Table 3).

Consequently, 33 manuscripts containing the results of 42 studies provided data that fulfilled all criteria and were used to perform the meta-analyses. Twenty-eight manuscripts were published in peer-reviewed journals, 3 were published as abstracts, one appeared as part of conference proceedings, and one was published as a book chapter. Thirty-one reports were written in English, 1 was in Portuguese, and 1 was in German. These references were categorized according to the continent where they were performed: 15 were carried out in America (Canada, United States, and Brazil), 13 in Europe, and 5 in Oceania (Australia and New Zealand).

Seven studies in 5 manuscripts did not report the SD (Ammerman et al., 1980; Aspila, 1991; Syrjala Qvist and Aspila, 1993; Malbe et al., 1995; Hemken et al., 1998); thereupon, their SD were imputed from all the other available studies and were included in the metaanalysis (Furukawa et al., 2006). Of the 33 references, 25 reported a positive effect of Se supplementation, 4 did not show a significant effect, and 4 did not report the significance of the effect. All 4 manuscripts, however, reported a numerically positive effect of Se supplementation on milk Se concentration (Table 4).

\section{Meta-Analysis}

The average treatment effect obtained by using the method-of-moments estimation was $0.16 \mu \mathrm{mol} / \mathrm{L}[95 \%$ confidence interval (CI): 0.117, 0.207], with significant heterogeneity among the studies. The variation in the difference in milk Se concentration attributable to the 
heterogeneity $\left(I^{2}\right)$ was estimated at $99.7 \%$, corresponding to a very strong between-study variation.

The average effect did not change when a meta-analysis was performed after removing those studies that did not report the SD (Table 5). Additionally, adjusting the overall variance by the variance inflation factor to summarize the milk Se concentration measured at different time points did not produce any change in the average effect or on its 95\% CI (Table 5). The results from each trial, the average effect of treatment, its $95 \%$ CI, and the prediction interval are shown in Figure 1.

\section{Publication Bias}

The statistical approaches used for the evaluation of publication bias showed differing results. Begg's test revealed a significant bias $(P<0.001)$, whereas the Egger's test did not suggest a significant bias $(P=0.28)$. The asymmetrical appearance (i.e., a gap in the lower left quadrant) in Figure 2 suggested that publication bias might be present. However, the average estimate, using the random-effects trim-and-fill method, did not result in any change in the effect of treatment obtained in the random-effects meta-analysis, and no missing studies were imputed.

\section{Meta-Regression Analyses}

None of the variables related to study quality (Table 1) recorded in the database showed a significant association with the outcome of interest. However, the effect of Se supplementation on milk Se concentration was less when cows were part of a randomized clinical trial $(P=$ $0.15)$. The unconditional analyses showed no significant association (data not shown) of the outcome variable with those variables related to the study design (Table 1), such as study population, production system, type of production, parity, frequency of Se administration, or days from treatment to first sample collection. A significant $(P<0.01)$ unconditional association with the outcome of interest was found for the continent where the study was carried out and the source of Se (Table 6). The relationship of milk Se concentration to dose of Se was nonlinear, which was indicated by the significance of a quadratic term for dose (Table 6).

Significant predictors remained in the multivariable model (Table 7). Two interactions were not presented in the table. The interaction between continent and source of Se was close to significant $(P=0.06)$, and the interaction between source of Se and the quadratic effect of dose was not significant $(P=0.48)$. Those interactions were omitted from the model. There were 2 somewhat extreme residuals corresponding to 2 trials in which Se yeast was used (Malbe et al., 1995; Guyot et 
Table 3. Summary of 5 studies reported in 3 references not having analysis of milk Se between 30 and 170 d from supplementation

\begin{tabular}{lllllllrrrr}
\hline Reference & & & & & & $\begin{array}{c}\text { Dose, } \\
\text { mg/d }\end{array}$ & Days $^{6}$ & $\begin{array}{c}\text { Milk Se, } \\
\mu \text { mol/L }\end{array}$ & $\begin{array}{c}\text { Mean } \\
\text { difference }^{7}\end{array}$ Significance $^{8}$ \\
\hline Fisher et al. (1980) & US & 3 & NR & L & Na-Sel. & 6.00 & 13 & 0.34 & 0.00 & NS \\
Fisher et al. (1980) & US & 3 & NR & L & Na-Sel. & 12.00 & 13 & 0.42 & 0.06 & NS \\
Jenkins et al. (1974) & CA & 8 & Mult. & D & Na-Sel. & 0.80 & 182 & 0.27 & 0.13 & NS \\
Jenkins et al. (1974) & CA & 8 & Mult. & D & Na-Sel. & 0.80 & 210 & 0.22 & 0.17 \\
Sustala et al. (2003) & CZ & 4 & Mult. & L & Yeast & 10.20 & 21 & 0.56 & 0.37 & S \\
\hline
\end{tabular}

${ }^{1}$ Country codes according to official short names in English as given in ISO 3166-1 and ISO 3166-1- $\alpha-2$ code elements.

${ }^{2} \mathrm{n}=$ number of cows.

${ }^{3}$ Parity: Mult. = multiparous; All $=$ first calving and multiparous; $\mathrm{NR}=$ not reported.

${ }^{4}$ Stage of lactation when the study started: $\mathrm{D}=$ dry period; $\mathrm{E}=$ from calving to $100 \mathrm{DIM}$ L = more than 100 DIM.

${ }^{5}$ Source of Se: Na-Sel. $=$ sodium selenite or selenate; yeast $=$ Se yeast.

${ }^{6}$ Days: lag time from supplementation to first milk sample collection for Se analysis.

${ }^{7}$ Mean difference $=$ difference between means for milk Se concentration of supplemented and unsupplemented cows.

${ }^{8}$ Significance: NS $=$ not significant; $\mathrm{S}=P<0.05$.

al., 2007). Their removal had little impact on estimates; consequently, those studies were retained in the model.

Milk Se concentration was predicted by using the coefficients of the multivariable regression model and was plotted against several doses of Se in the form of sodium selenite or selenate and Se yeast (Figure 3). For example, studies that administered Se yeast $(6 \mathrm{mg} /$ head per day) and were carried out in America had, on average, a milk Se concentration of $0.37 \mu \mathrm{mol} / \mathrm{L}$ greater than the concentration in cows supplemented with sodium selenite or selenate $75 \mathrm{~d}$ after the beginning of supplementation.

A sensitivity analysis was carried out by omitting 2 Australian trials that had a high predicted milk Se concentration after supplementation with Se yeast (Figure $3)$. In those trials, Se yeast was given at a dose greater than $10 \mathrm{mg} / \mathrm{h}$ per day (Heard et al., 2007). The analysis resulted in a nonsignificant effect of dose of Se, but the curves were similar to those shown in Figure 3.

A decrease in milk Se concentration was evident at doses of less than $3 \mathrm{mg} / \mathrm{h}$ per day; however, the effect of dose depended on Se source and changed according to the continent. On average, sodium selenite or selenate was supplemented at a dose of $3.2 \pm 1.6 \mathrm{mg} / \mathrm{h}$ per day and Se yeast was supplemented at $4.3 \pm 1.4 \mathrm{mg} / \mathrm{h}$ per day in American studies, whereas studies from Oceania supplemented $4.5 \pm 2.1 \mathrm{mg} / \mathrm{h}$ per day and $6.4 \pm 4.5$ $\mathrm{mg} / \mathrm{h}$ per day of sodium selenate or selenite and Se yeast, respectively.

\section{Cumulative Meta-Analysis}

The random-effects cumulative meta-analysis of the studies of oral Se supplementation and its effect on milk Se concentration published until 2007 is presented in Figure 4. A repeated pooled estimate and its 95\% CI after a sequential combination of the studies is displayed in order of ascending publication date. The first point of interest is the significant effect of Se supplementation on milk Se concentration from the first trial published in 1977. The studies showed the least response to Se supplementation from 1977 (Perry et al., 1977) to the early 1990s (Syrjala Qvist and Aspila, 1993). At that time, 336 cows had been allocated to 11 studies to compare the effect of sodium selenite or selenate supplementation $(3.2 \pm 1.3 \mathrm{mg} / \mathrm{h}$ per day) against the effect on unsupplemented cows.

The average effect started to change gradually toward a greater milk Se difference after the inclusion of Se yeast as a Se source in the early 1990s (Charmley et al., 1993). The results of the subsequent 31 studies, which enrolled 631 additional cows, increased the average effect of treatment, and its 95\% CI became wider. Moreover, the dose of Se was related to publication year and Se source. After 1993, sodium selenite or selenate was used, on average, at a dose of $3.6 \pm 1.8 \mathrm{mg} / \mathrm{h}$ per day compared with $5.0 \pm 2.8 \mathrm{mg} / \mathrm{h}$ per day when Se yeast was supplemented.

\section{Influential Studies}

A simple sensitivity assessment was performed by repeating the meta-analysis but excluding individual studies one at a time (Figure 5). No individual studies had an undue influence on the pooled estimate. However, omitting study 4 (Bis Wencel, 2003) had the largest effect on the pooled estimate, and in this case, the average treatment effect decreased from $0.16 \mu \mathrm{mol} / \mathrm{L}$ (95\% CI: $0.117,0.207)$ to $0.13 \mu \mathrm{mol} / \mathrm{L}(95 \%$ CI: 0.102 , $0.148)$.

\section{DISCUSSION}

A meta-analysis based on the results of the 42 studies meeting all selected criteria estimated an average 
increase in milk Se concentration of $0.16 \mu \mathrm{mol} / \mathrm{L}$ in response to oral Se supplementation (Table 5). However, results varied considerably among studies: continent, source of Se, and dose of Se were significant contributors to this variation (Table 6). Nonetheless, other factors such as study design, production system, previous Se status, type of production, supplementation protocol, duration of supplementation, and Se analysis methodology did not have a significant effect on the treatment response.

Two factors that might have contributed to the variation in supplementation response were stage of lactation and milk yield (Table 6). However, milk yield did not reduce the between-study variance. Although the stage of lactation was not significantly associated with the outcome, it explained $43 \%$ of the between-study vari-

Table 4. Summary of the 42 studies reported in 33 references used in the meta-analysis

\begin{tabular}{|c|c|c|c|c|c|c|c|c|c|c|}
\hline Reference & Country $^{1}$ & $\mathrm{n}^{2}$ & Parity $^{3}$ & Stage $^{4}$ & Source $^{5}$ & $\begin{array}{c}\text { Dose, } \\
\mathrm{mg} / \mathrm{h} \\
\text { per day }\end{array}$ & Days $^{6}$ & $\begin{array}{l}\text { Milk Se, } \\
\mu \mathrm{mol} / \mathrm{L}\end{array}$ & $\begin{array}{c}\text { Mean } \\
\text { difference }^{7}\end{array}$ & Significance $^{8}$ \\
\hline Ammerman et al. (1980) & US & 3 & Mult. & $\mathrm{D}$ & Na-Sel. & 1.26 & 133 & 0.16 & 0.04 & NS \\
\hline Aspila (1991) & FI & 11 & All & $\mathrm{L}$ & Na-Sel. & 6.20 & 77 & 0.15 & 0.06 & $\mathrm{~S}$ \\
\hline Batchelor (2002) & $\mathrm{AU}$ & 8 & Mult. & $\mathrm{L}$ & Yeast & 2.40 & 45 & 0.82 & 0.60 & $\mathrm{~S}$ \\
\hline Bis-Wencel (2003) & PL & 20 & Mult. & $\mathrm{E}$ & Na-Sel. & 0.60 & 79 & 1.34 & 0.30 & $\mathrm{~S}$ \\
\hline Brzoska and Brzoska (2004) & PL & 8 & Mult. & $\mathrm{E}$ & Na-Sel. & 4.83 & 84 & 0.23 & 0.10 & $\mathrm{~S}$ \\
\hline Charmley et al. (1993) & $\mathrm{CA}$ & 12 & All & $\mathrm{E}$ & Yeast & 5.00 & 56 & 0.44 & 0.27 & $\mathrm{~S}$ \\
\hline Conrad and Moxon (1979) & US & 5 & NR & $\mathrm{L}$ & Na-Sel. & 3.03 & 67 & 0.19 & 0.08 & NR \\
\hline Cuesta et al. (1993) & US & 21 & Mult. & $\mathrm{D}$ & Na-Sel. & 1.85 & 100 & 0.23 & 0.05 & $\mathrm{~S}$ \\
\hline Gierus et al. (2002) & DE & 10 & NR & $\mathrm{E}$ & Na-Sel. & 3.47 & 49 & 0.17 & 0.03 & $\mathrm{~S}$ \\
\hline Gierus et al. (2003) & DE & 20 & Mult. & $\mathrm{D}$ & Na-Sel. & 2.40 & 74 & 0.11 & 0.02 & NS \\
\hline Grace et al. (1997) & $\mathrm{NZ}$ & 20 & Mult. & $\mathrm{D}$ & Na-Sel. & 6.00 & 112 & 0.10 & 0.05 & $\mathrm{~S}$ \\
\hline Guyot et al. (2007) & $\mathrm{BE}$ & 6 & Mult. & $\mathrm{D}$ & Na-Sel. & 5.84 & 85 & 0.38 & 0.13 & $\mathrm{~S}$ \\
\hline Guyot et al. (2007) & $\mathrm{BE}$ & 6 & Mult. & $\mathrm{D}$ & Yeast & 5.84 & 85 & 1.65 & 1.39 & $\mathrm{~S}$ \\
\hline Heard et al. (2007) & $\mathrm{AU}$ & 6 & Mult. & $\mathrm{L}$ & Yeast & 11.64 & 32 & 1.45 & 1.11 & $\mathrm{~S}$ \\
\hline Heard et al. (2007) & $\mathrm{AU}$ & 6 & Mult. & $\mathrm{E}$ & Yeast & 10.94 & 32 & 1.26 & 1.10 & $\mathrm{~S}$ \\
\hline Hemken et al. (1998) & US & 4 & NR & $\mathrm{E}$ & Na-Sel. & 3.10 & 70 & 0.65 & -0.08 & $\mathrm{~S}$ \\
\hline Hemken et al. (1998) & US & 4 & NR & $\mathrm{E}$ & Na-Sel. & 6.30 & 70 & 0.76 & 0.04 & $\mathrm{~S}$ \\
\hline Hidiroglou and Proulx (1988) & $\mathrm{CA}$ & 6 & Prim & $\mathrm{D}$ & Na-Sel. & 2.70 & 120 & 0.11 & 0.04 & $\mathrm{~S}$ \\
\hline Hidiroglou et al. (1985) & $\mathrm{CA}$ & 23 & Mult. & $\mathrm{D}$ & Na-Sel. & 3.00 & 114 & 0.16 & 0.06 & $\mathrm{~S}$ \\
\hline Hidiroglou et al. (1987a) & $\mathrm{CA}$ & 49 & All & $\mathrm{D}$ & Na-Sel. & 4.00 & 90 & 0.16 & 0.01 & NS \\
\hline Hidiroglou et al. (1987b) & $\mathrm{CA}$ & 10 & Mult. & $\mathrm{D}$ & Na-Sel. & 2.50 & 120 & 0.12 & 0.06 & $\mathrm{~S}$ \\
\hline Juniper et al. (2006) & GB & 20 & Mult. & $\mathrm{E}$ & Na-Sel. & 2.25 & 35 & 0.26 & 0.02 & $\mathrm{~S}$ \\
\hline Juniper et al. (2006) & GB & 20 & Mult. & $\mathrm{E}$ & Yeast & 4.28 & 35 & 0.51 & 0.27 & $\mathrm{~S}$ \\
\hline Knowles et al. (1999) & $\mathrm{NZ}$ & 7 & NR & $\mathrm{L}$ & Na-Sel. & 3.00 & 88 & 0.17 & 0.09 & $\mathrm{~S}$ \\
\hline Knowles et al. (1999) & $\mathrm{NZ}$ & 7 & NR & $\mathrm{L}$ & Yeast & 3.00 & 88 & 0.51 & 0.43 & $\mathrm{~S}$ \\
\hline Malbe et al. (1995) & $\mathrm{EE}$ & 4 & NR & $\mathrm{L}$ & Na-Sel. & 4.20 & 56 & 0.30 & 0.25 & NR \\
\hline Malbe et al. (1995) & $\mathrm{EE}$ & 4 & NR & $\mathrm{L}$ & Yeast & 4.20 & 56 & 0.81 & 0.75 & NR \\
\hline McDowell et al. (2002) & US & 8 & Mult. & $\mathrm{D}$ & Yeast & 2.10 & 140 & 0.44 & 0.06 & $\mathrm{~S}$ \\
\hline McIntosh and Royle (2002) & $\mathrm{AU}$ & 3 & Mult. & $\mathrm{L}$ & Yeast & 4.00 & 42 & 0.26 & 0.17 & $\mathrm{~S}$ \\
\hline Muniz-Naveiro et al. (2005) & ES & 12 & NR & $\mathrm{L}$ & Na-Sel. & 2.87 & 35 & 0.30 & 0.02 & $\mathrm{~S}$ \\
\hline Muniz-Naveiro et al. (2005) & $\mathrm{ES}$ & 12 & NR & $\mathrm{L}$ & Yeast & 2.84 & 35 & 0.39 & 0.11 & $\mathrm{~S}$ \\
\hline Ortman and Pehrson (1999) & $\mathrm{SE}$ & 10 & All & $\mathrm{E}$ & Na-Sel. & 3.00 & 63 & 0.21 & 0.04 & $\mathrm{~S}$ \\
\hline Ortman and Pehrson (1999) & $\mathrm{SE}$ & 11 & All & $\mathrm{E}$ & Yeast & 3.00 & 63 & 0.40 & 0.23 & $\mathrm{~S}$ \\
\hline Paschoal et al. (2007) & $\mathrm{BR}$ & 8 & All & $\mathrm{L}$ & Yeast & 5.00 & 56 & 0.40 & 0.05 & $\mathrm{~S}$ \\
\hline Perry et al. (1977) & US & 3 & Mult. & $\mathrm{D}$ & Na-Sel. & 2.67 & 144 & 0.14 & 0.04 & NR \\
\hline Phipps et al. (2007) & UK & 10 & Mult. & $\mathrm{L}$ & Yeast & 4.95 & 112 & 0.84 & 0.53 & $\mathrm{~S}$ \\
\hline Phipps et al. (2007) & UK & 10 & Mult. & $\mathrm{L}$ & Na-Sel. & 3.22 & 112 & 0.50 & 0.18 & $\mathrm{~S}$ \\
\hline Salih et al. (1987) & US & 12 & All & $\mathrm{D}$ & Na-Sel. & 3.50 & 90 & 0.08 & 0.02 & $\mathrm{~S}$ \\
\hline Stowe et al. (1988) & US & 38 & Mult. & $\mathrm{D}$ & Na-Sel. & 2.00 & 67 & 0.26 & -0.02 & NS \\
\hline Syrjala Qvist and Aspila (1993) & FI & 11 & All & $\mathrm{L}$ & Na-Sel. & 4.07 & 109 & 0.17 & 0.07 & NR \\
\hline Waldron et al. (2004) & US & 10 & Mult. & $\mathrm{L}$ & Na-Sel. & 7.50 & 42 & 0.11 & 0.03 & $\mathrm{~S}$ \\
\hline Wiewiora et al. (2003) & PL & 8 & Mult. & $\mathrm{E}$ & Na-Sel. & 2.10 & 83 & 0.07 & 0.02 & $\mathrm{~S}$ \\
\hline
\end{tabular}

${ }^{1}$ Country codes according to official short names in English as given in ISO 3166-1 and ISO 3166-1- $\alpha-2$ code elements.

${ }^{2} \mathrm{n}=$ number of cows.

${ }^{3}$ Parity: Prim = primiparous; Mult. = multiparous; All = first calving and multiparous; $\mathrm{NR}=$ not reported.

${ }^{4}$ Stage of lactation when the study started: $\mathrm{D}=$ dry period; $\mathrm{E}=$ from calving to $100 \mathrm{DIM}$ L = more than 100 DIM.

${ }^{5}$ Source of Se: Na-Sel. = sodium selenite or selenate; yeast $=$ Se yeast.

${ }^{6}$ Days: lag time from supplementation to first milk sample collection for Se analysis.

${ }^{7}$ Mean difference: difference between means for milk Se concentration of supplemented and unsupplemented cows.

${ }^{8}$ Significance: NS $=$ not significant; $\mathrm{S}=P<0.05$. 
Table 5. Average effect of oral Se supplementation on milk Se concentration obtained after removing the studies that did not report the SD or after adjusting the overall variance by the variance inflation factor $(\mathrm{VIF})^{1}$

\begin{tabular}{llccc}
\hline Item & $\mathrm{n}^{2}$ & $T$ & $95 \% \mathrm{CI}$ & $\tau^{2}$ \\
\hline Actual estimate & 42 & 0.162 & $0.117,0.207$ & 0.0192 \\
SD reported & 35 & 0.163 & $0.114,0.211$ & 0.0192 \\
Adjusting by VIF & & & & \\
$\quad \rho=0.90$ & 42 & 0.161 & $0.116,0.206$ & 0.0185 \\
$\rho=0.75$ & 42 & 0.161 & $0.116,0.206$ & 0.0186 \\
$\rho=0.25$ & 42 & 0.162 & $0.117,0.207$ & 0.0190 \\
\hline
\end{tabular}

${ }^{1}$ Table presents the average effect $(T), 95 \%$ confidence interval $(95 \% \mathrm{CI})$, and method-of-moments estimator of the between-study variance $\left(\tau^{2}\right)$.

${ }^{2}$ Number of studies.

${ }^{3} \rho=$ intraclass correlation coefficient.

ance. Milk yield was not reported in all studies, and its effect was evaluated by using the results of 11 studies. A recent study found that milk Se concentration was associated with stage of lactation, where early-lactation cows had lower milk Se concentration than did latelactation cows and where that effect was likely mediated by a simple dilution effect of milk yield (Wichtel et al., 2004).

A critical examination for the presence of publication bias, or other bias types, is an integral part of the meta-analysis process (Egger et al., 1997). In this case, visual assessment (Figure 2) indicated weak evidence of the presence of publication bias, but Egger's test was not significant and the trim-and-fill test did not impute any study. The asymmetry observed in the funnel plot might be an indication of the inclusion of studies of poorer quality (e.g., poor methodological design of small studies). On average, smaller studies are conducted and analyzed with less methodological rigor than are larger studies (Egger et al., 1997). The effect of small studies on the assessment of publication bias has not gone unnoticed, and a significant exaggeration of the treatment response has been observed when results of poorer quality trials have been pooled (Moher et al., 1998). In this meta-analysis, the fact of whether the experimental units were randomly allocated to groups was weakly associated with the study outcome. The effect of Se supplementation on milk Se concentration tended to be smaller when cows were randomly allocated to the experimental groups $(\beta=-0.12, P=$ 0.146), supporting the contention that smaller studies tend to overestimate the effect of the treatment (Egger et al., 1997; Moher, et al., 1998). However, the average effect was not modified, regardless of whether the study was published in a peer-reviewed journal, which might reflect a better quality of study.

With regard to the meta-regression analysis, in the univariate analysis, supplementation with Se yeast resulted in a greater milk Se concentration compared with supplementation with sodium selenite or selenate. Studies in which Se yeast was used tended to supplement at greater doses than did studies in which inorganic sources were administered, and studies performed in Oceania used even greater doses of both sources than did studies performed in America or Europe. This is an indication that Se source might be affected by continent (i.e., confounding effect), because these variable was also related to milk Se concentration.

A lack of effect on predicted milk Se concentration was observed when less than $3 \mathrm{mg} / \mathrm{h}$ per day was given (Figure 3), which might be related to individual responses that caused a high variability in milk Se concentration across studies. Weiss (2005) described a linear relationship of Se dose to milk Se concentration, with the latter not changing greatly as intake of inorganic sources increased. Based on this linear regression, a change in Se intake from 2 to $5 \mathrm{mg} / \mathrm{h}$ per day when inorganic sources were supplemented would result in an increase in milk Se concentration of $0.06 \mu \mathrm{mol} / \mathrm{L}$, but this association was not controlled for potential confounders. A low positive increase in milk Se concentration was also observed in a trial performed in England, in which incremental doses of inorganic Se were given (Givens et al., 2004). In contrast, the metaregression in this study showed that an increase from 2 to $5 \mathrm{mg} / \mathrm{h}$ per day in Se intake when inorganic Se was fed would cause a decrease in milk Se concentration of $0.04 \mu \mathrm{mol} / \mathrm{L}$, and the magnitude and direction of that change were related to continent and Se dose, as shown in Table 7 and Figure 3.

Particular characteristics of soils, forages, and cattle production in America and Europe compared with Oceania and characteristics of Se yeast may account for the different strategies used in the design of trials on Se supplementation, hence the suggestion that continent, source, and dose were associated and acted as potential confounders. It has been recognized that Australia, and New Zealand in particular, where cattle 


\section{Study Reference}

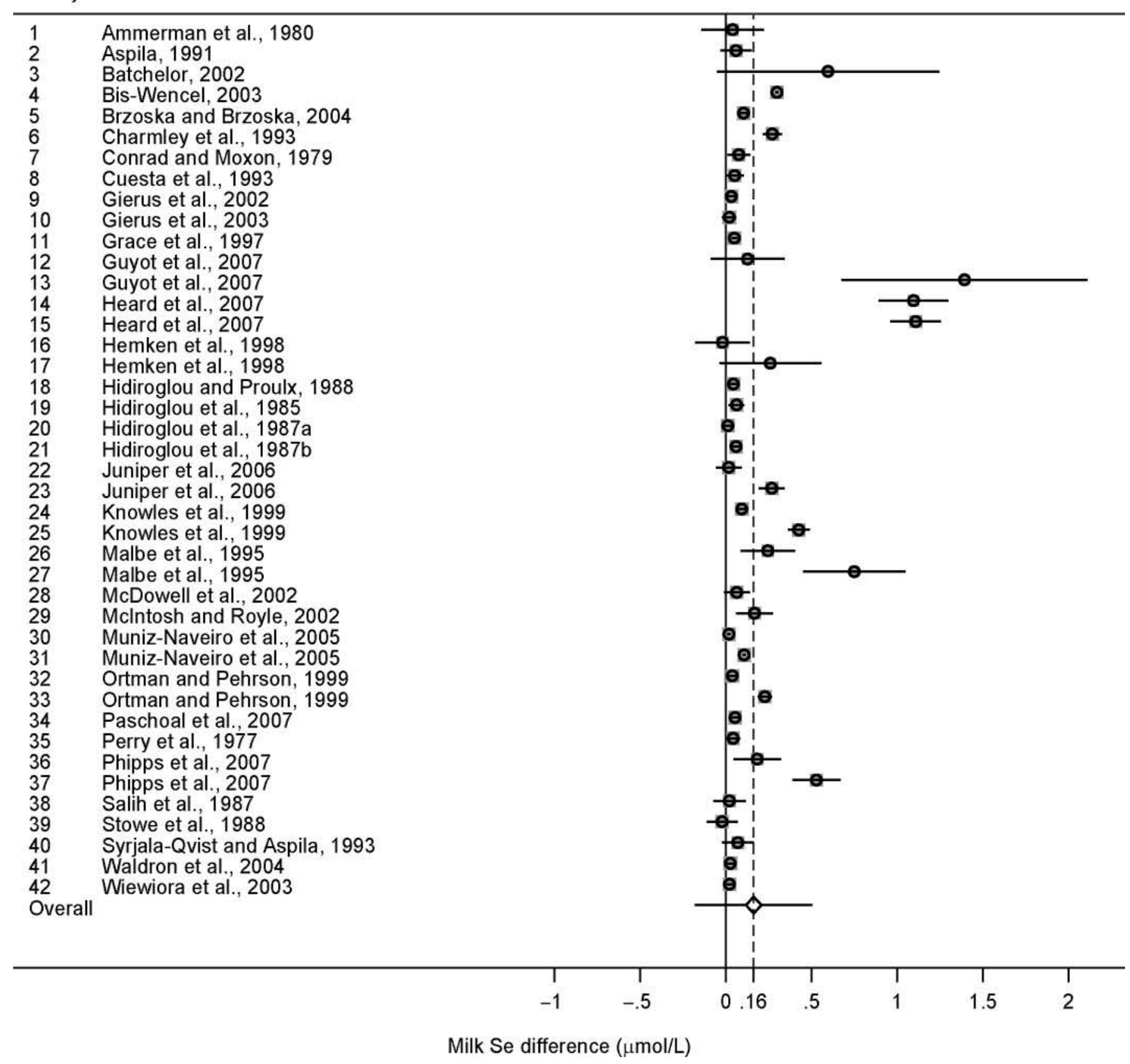

Figure 1. Forest plot of the effect of oral Se supplementation on milk Se concentration $(\mu \mathrm{mol} / \mathrm{L})$ difference in cattle. The average estimate of the effect was derived from the random-effects meta-analysis. The length of the horizontal line represents the $95 \%$ confidence interval (CI) for the effect size from each study, the center of the square $(\bigcirc)$ represents the point estimate from that study, and the area of the square is proportional to the weight assigned to the study. The dashed line is the average effect of treatment $(0.16 \mu \mathrm{mol} / \mathrm{L})$ obtained from the analysis, whereas the solid vertical line marks the value at which Se supplementation would have no effect. The diamond $(\diamond)$ at the bottom of the dashed line shows the $95 \%$ CI for the overall effect $(0.117,0.207)$, and the horizontal line beside the diamond represents the prediction interval $(95 \%$ : $-0.17,0.50$ $\mu \mathrm{mol} / \mathrm{L})$ for the milk Se difference in future studies.

production is pasture based, have Se-deficient soils because of low $\mathrm{pH}$ and rainfall (Australia) or volcanic parent material (New Zealand), and both countries are acknowledged as pioneers in Se research in livestock
(Oldfield, 2002). Factors such as the recognition of deficiency (Oldfield, 2002); previous data on low milk Se concentration from Australia (Heard et al., 2004), England (Givens et al., 2004), Estonia (Pehrson et al., 
Table 6. Univariable meta-regression based on 42 studies of Se supplementation in cattle ${ }^{1}$

\begin{tabular}{|c|c|c|c|c|}
\hline Factor & $\beta$ & $95 \% \mathrm{CI}$ & $P$ & $\tau^{2}$ \\
\hline Null model & 0.162 & $0.083,0.241$ & $<0.01$ & 0.019 \\
\hline Random allocation & -0.115 & $-0.276,0.045$ & 0.15 & 0.019 \\
\hline Continent & & & $<0.01$ & 0.019 \\
\hline America $^{2}$ & Baseline & & & \\
\hline Europe & 0.100 & $-0.051,0.253$ & 0.19 & \\
\hline Oceania $^{3}$ & 0.379 & $0.167,0.591$ & $<0.01$ & \\
\hline Stage of lactation & & & 0.13 & 0.011 \\
\hline Dry period ${ }^{4}$ & Baseline & & & \\
\hline Early lactation $(<100$ DIM $)$ & 0.133 & $-0.047,0.314$ & 0.14 & \\
\hline Late lactation ( $>100$ DIM) & 0.168 & $-0.004,0.339$ & 0.06 & \\
\hline Milk yield $\left(\mathrm{n}=9^{5}\right)$ & -0.035 & $-0.094,0.025$ & 0.213 & 0.038 \\
\hline Source & & & & 0.027 \\
\hline Sodium selenite or selenate & Baseline & & & \\
\hline Se yeast & 0.333 & $0.190,0.476$ & $<0.01$ & \\
\hline Dose & -0.102 & $-0.179,-0.026$ & 0.01 & 0.005 \\
\hline Quadratic term & 0.015 & $0.008,0.021$ & $<0.01$ & \\
\hline Days & -0.002 & $-0.005,0.000$ & 0.08 & 0.019 \\
\hline
\end{tabular}

${ }^{1}$ Table presents coefficients ( $\beta$ ), $95 \%$ confidence interval (95\% CI), $P$-values, and the method-of-moments estimator of the between-study variance $\left(\tau^{2}\right)$.

${ }^{2}$ Canada, the United States, and Brazil.

${ }^{3}$ Australia and New Zealand.

${ }^{4}$ Dry period corresponds to beginning Se supplementation before calving.

${ }^{5}$ Milk production was reported in only 9 studies.

1997), New Zealand (Grace et al., 1997; Knowles et al., 1999), Nordic countries (Ekholm et al., 1991), and North America (Maus et al., 1980); and the small contribution of livestock-derived food products to the Se intake of humans from several countries (Combs, 2001) might be related to the choice of different doses for Se supplementation trials, where the objective was to enhance the Se status in animals and the intake of Se for consumers. Thus, Australian reports have described the use of supranutritional doses of Se yeast in an attempt

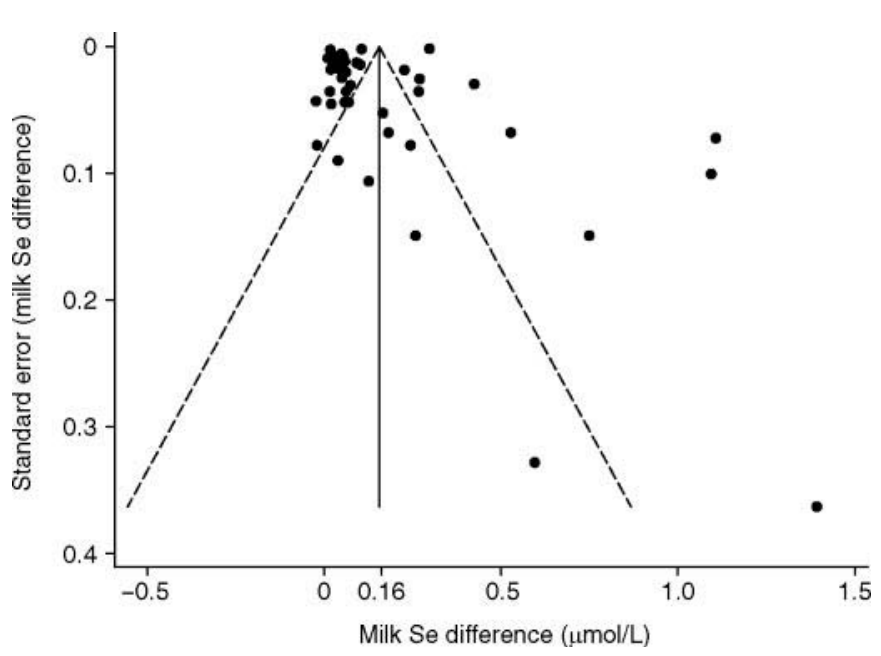

Figure 2. Funnel plot of the point estimates of the effect of oral Se supplementation on the difference of milk Se concentration $(\mu \mathrm{mol} / \mathrm{L})$ in cattle. to increase the content of Se in milk (Heard et al., 2004, 2007), whereas American studies have been carried out to adjust them to lower Se intakes, reflecting NRC (2001) recommendations. Moreover, Se intake is legally restricted in North America but not in Oceania, and this may affect the choice for greater doses.

The biological properties of Se yeast may also account for the observed response in milk Se concentration. Recently, a narrative review suggested that Se concentration was increased by $90 \%$ when cattle were

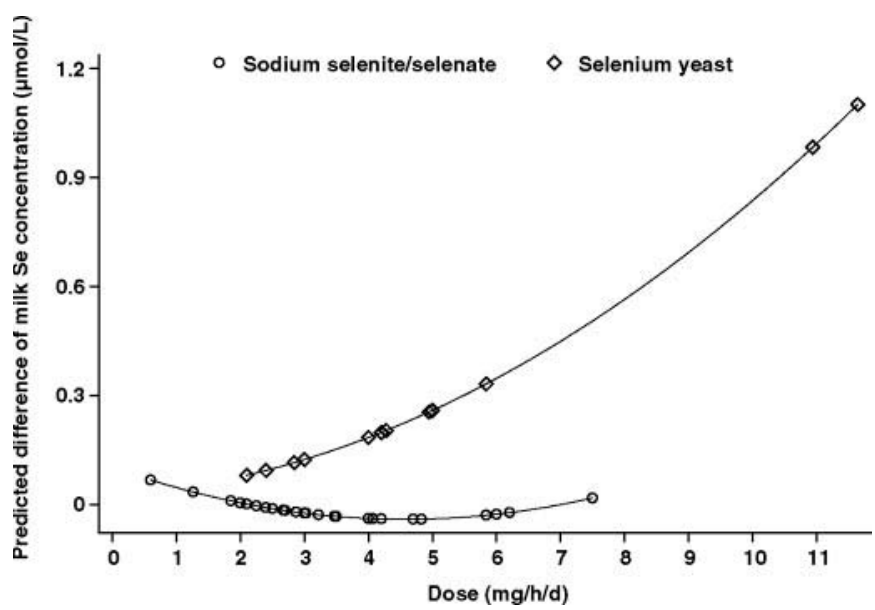

Figure 3. Effect of the dose of Se $(\mathrm{mg} / \mathrm{h}$ per day) on milk Se concentration $(\mu \mathrm{mol} / \mathrm{L}) 75 \mathrm{~d}$ after the beginning of supplementation, predicted according to the multivariable regression model for a study carried out in America (Canada, the United States, and Brazil; symbols indicate the actual doses among the 42 studies). 
Table 7. Multivariable meta-regression based on 42 studies of Se supplementation in cattle

\begin{tabular}{|c|c|c|c|c|}
\hline Factor & $\beta$ & $95 \% \mathrm{CI}$ & $P$ & $\tau^{2}$ \\
\hline Null model & 0.162 & $0.083,0.241$ & $<0.01$ & 0.019 \\
\hline Multivariable model & & & $<0.01$ & 0.006 \\
\hline Intercept & 0.001 & $-0.189,0.191$ & 0.99 & \\
\hline Continent & & & $<0.01$ & \\
\hline America $^{2}$ & Baseline & & & \\
\hline Europe & 0.118 & $0.043,0.193$ & $<0.01$ & \\
\hline Oceania $^{3}$ & 0.116 & $0.010,0.222$ & 0.03 & \\
\hline Se yeast & -0.080 & $-0.297,0.138$ & 0.47 & \\
\hline Dose & -0.063 & $-0.124,-0.001$ & 0.05 & \\
\hline Dose_sq & 0.007 & $-0.000,0.014$ & 0.05 & \\
\hline Days & 0.001 & $0.000,0.003$ & 0.04 & \\
\hline \multicolumn{5}{|l|}{ Interaction } \\
\hline Source $\times$ dose & 0.075 & $0.024,0.127$ & $<0.01$ & \\
\hline
\end{tabular}

${ }^{1}$ Table presents coefficients ( $\beta$ ), $95 \%$ confidence interval (95\% CI), $P$-values, and the method-of-moments estimator of the between-study variance $\left(\tau^{2}\right)$.

${ }^{2}$ Canada, the United States, and Brazil.

${ }^{3}$ Australia and New Zealand.

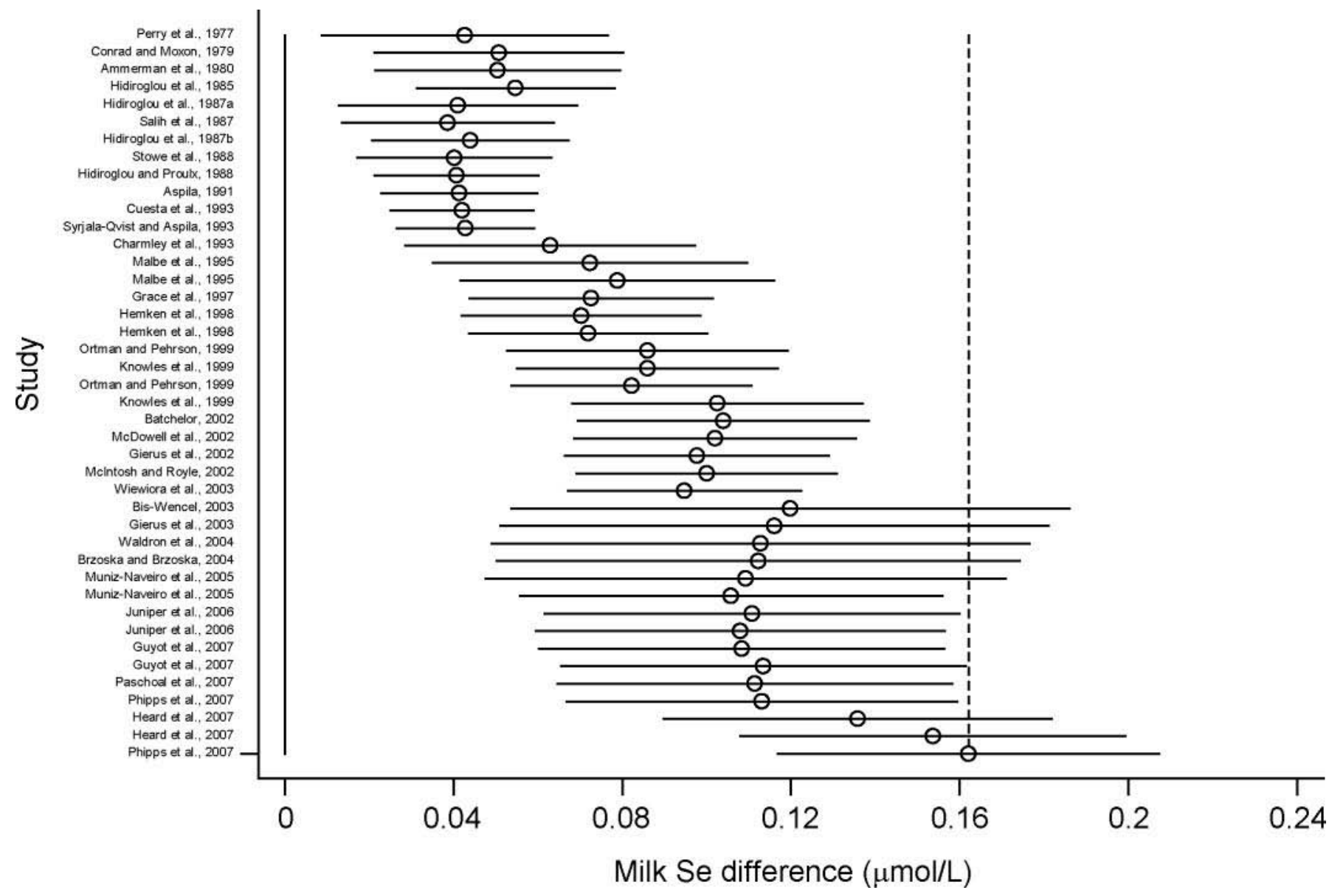

Figure 4. Cumulative meta-analysis of 42 studies of the effect of Se supplementation on milk Se concentration $(\mu \mathrm{mol} / \mathrm{L})$ difference in cattle, ordering by year of publication. The figure displays repeated average effect estimates $(\bigcirc)$, and their $95 \%$ confidence intervals (horizontal line) for the analysis performed after adding each study. The solid vertical line marks the value at which supplementation would have no effect, and the dashed vertical line marks the current average effect of treatment. 


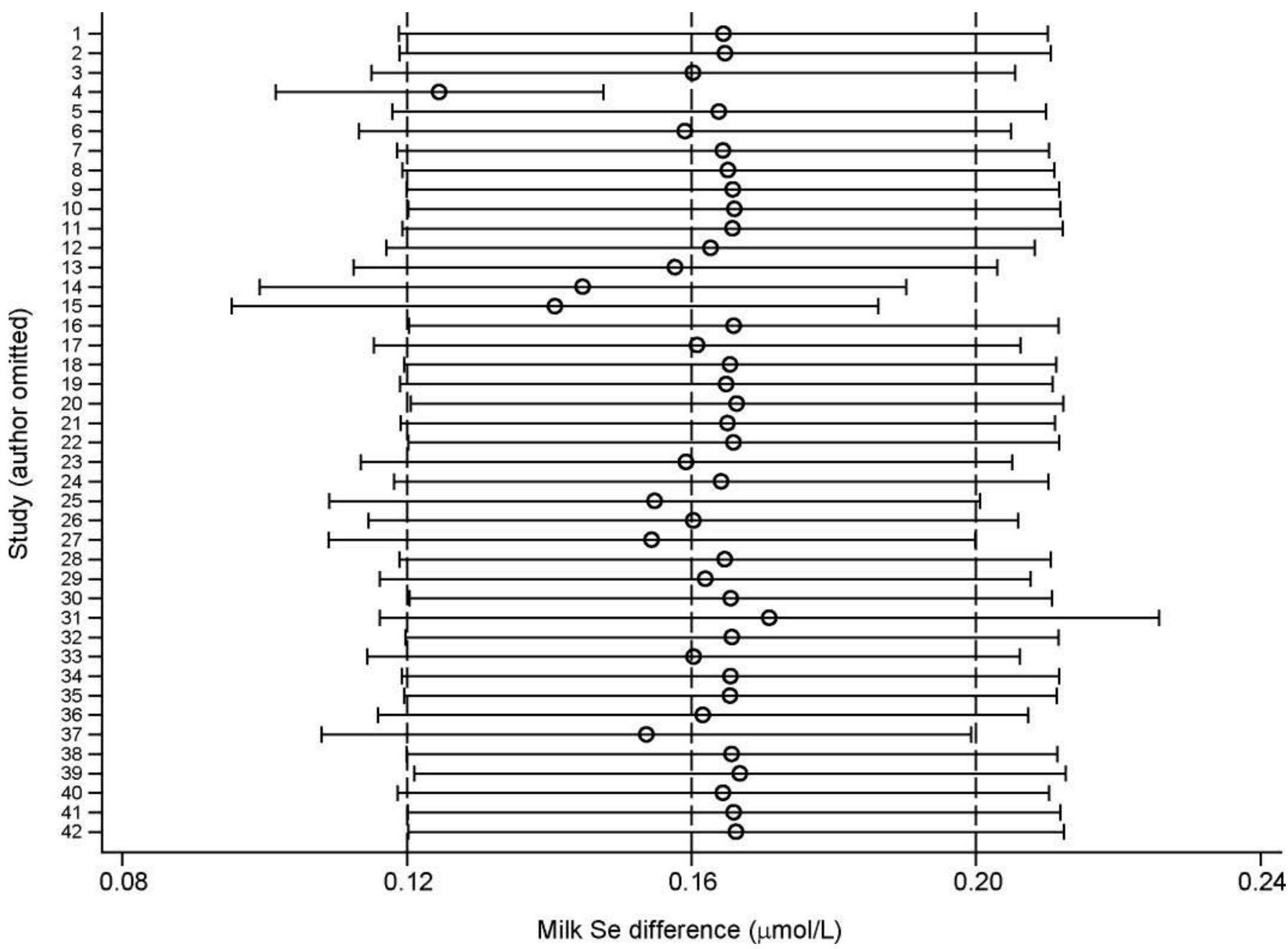

Figure 5. Influence plot of 42 studies of the effect of Se supplementation on milk Se concentration ( $\mu$ mol/L) difference in cattle. The figure displays the average estimate $(\bigcirc)$ of the effect and its $95 \%$ confidence interval (each horizontal line) for the meta-analysis repeated systematically, excluding each individual study at a time (refer to Figure 1 for study identification).

fed Se yeast compared with an inorganic source (Weiss, 2005). Selenium yeast is a dried nonviable yeast ( $\mathrm{Sac}$ charomyces cerevisiae) product. The yeast is cultivated by using a fed-batch fermentation process that provides incremental amounts of Se salts, minimizing the detrimental effects of Se salts on the yeast. This allows for the optimal incorporation of inorganic Se into cellular organic material, acquiring properties similar to natural Se sources (Weiss, 2005). Organic Se yeast contains a variety of Se proteins, mainly selenomethionine (Se-Met), and other low molecular weight selenocompounds. Even though little information is available concerning Se yeast metabolism in ruminants, it appears that Se coming from Se yeast is probably better absorbed than inorganic forms of Se (Weiss, 2005). In vitro studies found a better diffusibility of Se-Met, which contributes to its high absorption in vivo (Shen et al., 1997). Moreover, Se yeast is better transferred to milk than are inorganic Se sources (Knowles et al., 1999; Pehrson, 2005; Juniper et al., 2006), probably because of the AA composition of milk proteins. Milk has a Met concentration approximately 2 times greater than blood protein. Therefore, it is 2 times more likely that Se-Met will be incorporated into milk protein than blood protein (Weiss, 2005).

The recommended dietary intake of Se for humans depends on sex and age but, on average, a daily intake between 26 and $55 \mu \mathrm{g}$ meets the requirement for adults. This intake must be greater in pregnant or lactating women (Institute of Medicine, 2000; World Health Organization/Food and Agriculture Organization of the United Nations, 2004). According to the meta-regression analysis, to provide at least $10 \%$ of the minimum recommended dietary intake for Se when $100 \mathrm{~mL}$ of 
milk will be consumed daily, cows in America should be fed at least $11 \mathrm{mg}$ of sodium selenite or selenate/h per day or $6 \mathrm{mg}$ of Se yeast/h per day to comply with the suggestions of the Institute of Medicine (2000) and World Health Organization/Food and Agriculture Organization of the United Nations (2004) for Se daily intake.

The pattern observed after the cumulative metaanalysis (Figure 4), which was the change toward a greater effect, might have been the result of a combination of several factors, such as an improvement in study designs (i.e., use of more powerful statistical analysis); amendment to allowable Se supplementation in the United States in 1987, which allowed $0.3 \mathrm{mg} / \mathrm{kg}$ (on a DM basis) of supplemental Se to be added to ruminant diets (Ullrey, 1992); the marketing of Se yeast, which began in the early 1990s; and approval for its use in cattle in 2003 (US Food and Drug Administration, 2003). However, the effect of source across years might have been confounded by other factors (e.g., previous Se status, age of the cow, stage of lactation) that did not show any significant association with milk Se concentration in this study.

The average effect decreased slightly after the removal of study 4 (Bis Wencel, 2003). The effect decreased by $18 \%$ but remained positive (Figure 5 ). That particular study was performed in Europe (Poland) and used sodium selenate as the Se source $(0.6 \mathrm{mg} / \mathrm{h}$ per day). A large increase in milk Se concentration was found in supplemented cows $(0.30 \mu \mathrm{mol} / \mathrm{L})$ compared with unsupplemented ones. The study had a relatively large sample size ( $\mathrm{n}=20$ cows), and the precision of the estimate was high (SE: $0.001 \mu \mathrm{mol} / \mathrm{L})$, which is an indication of a strong influence on the average effect of treatment. However, this study was neither blinded nor were cows randomly allocated to treatments, and the cows in the unsupplemented group had a greater milk Se concentration than cows from other trials. In spite of having a high milk Se concentration, the cows in this trial responded favorably to low Se supplementation with inorganic Se.

\section{CONCLUSIONS}

On average, an increase of $0.16 \mu \mathrm{mol} / \mathrm{L}$ in milk Se concentration might be expected after oral Se supplementation in cattle, and an effect on milk Se concentration between -0.17 and $0.50 \mu \mathrm{mol} / \mathrm{L}$ (95\% certainty) might be expected in future clinical trials conducted to evaluate the effect of oral Se supplementation on milk Se concentration. High variation among studies was observed, in part because of geographic factors and some characteristics related to study design (e.g., stage of lactation, Se source, dose of Se). There was weak evidence of publication bias. The effect of the dose of Se was unexpectedly low when Se was given to cows at a dose of less than $3 \mathrm{mg} / \mathrm{h}$ per day. However, other studies reporting a linear relationship did not account for potential confounders (i.e., source of Se). Greater doses of Se (i.e., organic forms) are required to achieve an adequate milk Se concentration for human consumption according to the country where the study will be performed. It has been suggested that seleno-AA from Se yeast are metabolized by mechanisms distinct from those of inorganic forms and may be the form of choice for enhancing milk Se concentration. The challenge is to tailor the Se form and supplementation protocols to meet animal dietary requirements and to benefit consumers of dairy products.

\section{REFERENCES}

Acevedo-Maldonado, N., P. F. Randel, and E. O. Riquelme. 1999. Supplementation of selenium in dairy cows using ruminal bolus or injections. J. Agric. Univ. Puerto Rico. 83:223-228.

Ammerman, C. B., H. L. Chapman, G. W. Bouwman, J. P. Fontenot, C. P. Bagley, and A. L. Moxon. 1980. Effect of supplemental selenium for beef cows on the performance and tissue selenium concentrations of cows and suckling calves. J. Anim. Sci. 51:13811386.

Aspila, P. 1991. Metabolism of selenite, selenomethionine and feedincorporated selenium in lactating goats and dairy cows. J. Agric. Sci. Finl. 63:1-74.

Awadeh, F. T., R. L. Kincaid, and K. A. Johnson. 1998. Effect of level and source of dietary selenium on concentrations of thyroid hormones and immunoglobulins in beef cows and calves. J. Anim. Sci. $76: 1204-1215$.

Barthelmy, D. 2005. Selenium. http://webmineral.com/data/Selenium. shtml. Accessed May 26, 2008.

Batchelor, J. 2002. Supplementing selenium to pasture-based dairy cows. Sel-Plex 136. Alltech Inc., Nicholasville, KY.

Binnerts, W. T., J. Rijken, and T. C. Viets. 1984. The selenium content in milk as an indicator of the selenium status of cows. Pages 129 137 in Trace Element-Analytical Chemistry in Medicine and Biology. P. Bratter, and P. Schramel, ed. Walter de Gruyter and Co., Berlin, Germany.

Bis Wencel, H. 2003. Mineral elements level in milk of the cows with mineral dietary supplementation. Ann. U. Mariae CurieSklodowska Sec. EE 21:259-264.

Brzoska, F. 2004. Effect of calcium salts of fatty acids and selenium on cows' milk yield and composition. Ann. Anim. Sci. 4:69-78.

Brzoska, F., and B. Brzoska. 2004. Effect of dietary selenium on milk yield of cows and chemical composition of milk and blood. Ann. Anim. Sci. 4:57-67.

Carver, J. D. 2003. Advances in nutritional modifications of infant formulas. Am. J. Clin. Nutr. 77(Suppl.):1550S-1554S.

Charlton, P. 1995. Sel-Plex ${ }^{\mathrm{TM}}$ supplementation increases glutathione peroxidase activity in dairy cows: Field results from Britain. SelPlex 025. Alltech Inc., Nicholasville, KY.

Charmley, E., J. W. G. Nicholson, and J. A. Zee. 1993. Effect of supplemental vitamin $\mathrm{E}$ and selenium in the diet on vitamin $\mathrm{E}$ and selenium levels and control of oxidized flavor in milk from Holstein cows. Can. J. Anim. Sci. 73:453-457.

Coe, P. H., J. Maas, J. Reynolds, and I. Gardner. 1993. Randomized field trial to determine the effects of oral selenium supplementation on milk production and reproductive performance of Holstein heifers. J. Am. Vet. Med. Assoc. 202:875-881.

Combs, G. F. Jr. 2001. Selenium in global food systems. Br. J. Nutr. $85: 517-547$. 
Conrad, H. R., and A. L. Moxon. 1979. Transfer of dietary selenium to milk. J. Dairy Sci. 62:404-411.

Conrad, H. R., and A. L. Moxon. 1980. Selenium requirements for dairy cows. Ohio Rep. Res. Dev. 65:8-9.

Cuesta, P. A. 1992. Effect of supplemental selenium and vitamin E on serum and milk concentrations of cattle and sheep, tissue selenium concentrations and mineral status of grazing cattle in North Florida. PhD Thesis. Univ. Florida, Gainesville, FL.

Cuesta, P. A., L. R. McDowell, W. E. Kunkle, F. Bullock, A. Drew, N. S. Wilkinson, and F. G. Martin. 1993. Serum selenium and vitamin $\mathrm{E}$, and selenium concentration in liver, milk and hair as affected by supplementation to beef cattle. Int. J. Anim. Sci. 8:257-262.

Cuesta, P. A., L. R. McDowell, W. E. Kunkle, N. S. Wilkinson, and F. G. Martin. 1994. Effects of high doses of selenium and vitamin E injected into cows prepartum on milk and serum concentrations of these nutrients. Int. J. Anim. Sci. 9:275-278.

Culleton, N., P. Parle, J. Murphy, and P. Rodgers. 1993. Selenium supplementation of dairy cows. Vet. Surg. 15:20-22.

Culleton, N., P. J. Parle, P. A. Rogers, W. E. Murphy, and J. Murphy. 1997. Selenium supplementation for dairy cows. Ir. J. Agric. Food Res. 36:23-29.

De Toledo, L. R. A., and T. W. Perry. 1985. Distribution of supplemental selenium in the serum, hair, colostrum, and fetus of parturient dairy cows. J. Dairy Sci. 68:3249-3254.

Deeks, J. J., D. G. Altman, and M. J. Bradburn. 2001. Statistical methods for examining heterogeneity and combining results from several studies in meta-analysis. Pages 285-312 in Systematic Reviews in Health Care: Meta-analysis in Context. M. Egger, G. D. Smith, and D. G. Altman, ed. BMJ Books, London, UK.

Dell, W. J. 1974. Factors affecting the incidence of autoxidized milk. PhD Thesis. Univ. Georgia, Athens.

DerSimonian, R., and N. Laird. 1986. Meta-analysis in clinical trials. Control. Clin. Trials 7:177-188.

Diaz, D. E., M. Casagrandi, A. Tampieri, L. Piccinni, and P. Geliot. 2005. Increases in milk selenium concentrations and decreases in somatic cell counts in dairy cattle consuming Sel-Plex ${ }^{\mathrm{TM}}$. Alltech Inc., Nicholasville, KY.

Dohoo, I., W. Martin, and H. Stryhn. 2003. Veterinary Epidemiologic Research. AVC Inc., Charlottetown, PEI, Canada.

Duval, S., and R. Tweedie. 2000. A nonparametric "trim and fill" method of accounting for publication bias in meta-analysis. J. Am. Stat. Assoc. 95:89-98.

Egger, M., G. D. Smith, and K. O'Rourke. 2001. Rationale, potential and promise of systematic reviews. Pages 3-19 in Systematic Reviews in Health Care: Meta-analysis in Context. M. Egger, G. D. Smith, and D. G. Altman, ed. BMJ Books, London, UK.

Egger, M., G. D. Smith, M. Schneider, and C. Minder. 1997. Bias in meta-analysis detected by a simple, graphical test. BMJ 315:629634.

Ekholm, P. I., M. E. Ylinen, M. H. Eurola, P. E. Koivistoinen, and P. T. Varo. 1991. Effects of general soil fertilization with sodium selenate in Finland on the selenium content of milk, cheese and eggs. Milchwissenschaft 46:547-550.

Enjalbert, F., P. Lebreton, O. Salat, and F. Schelcher. 1999. Effects of pre- or postpartum selenium supplementation on selenium status in beef cows and their calves. J. Anim. Sci. 77:223-229.

Essick, L. A., and D. J. Lisk. 1987. Selenium in milk of dairy cows fed the newly legalized $0.3 \mathrm{ppm}$ selenium-supplemented diet. J. Food Saf. 8:255-259

Eversole, D. E., W. S. Swecker Jr., C. D. Thatcher, D. J. Blodgett, and G. G. Schurig. 1992. Selenium supplementation increases colostral IgG in beef cows. Virginia Tech. Livest. Res. Rep. 10:76-77.

Falkowska, A., D. Minakowski, and J. Tywonczuk. 2000. The effect of supplementing rations with selenium and vitamin $\mathrm{E}$ on biochemical parameters in blood and performance of cows in the early stage of lactation. J. Anim. Feed Sci. 9:271-282.

Fan, Y. K., I. T. Lin, and H. I. Chang. 2006. Effect of preparturient intramuscular injection of vitamin $\mathrm{E}$ and selenium on milk somatic cell counts in Holstein cows. J. Anim. Sci. 84(Suppl. 1):398-399.

Fisher, D. D. 1995. Comparative effects of inorganic and organic selenium sources (selenium yeast) on selenium status of lactating cows. Pages 271-281 in Biotechnology in the Feed Industry: Proceedings of Alltech's 11th Annu. Symp. T. P. Lyons, and K. A. Jacques, ed. Nottingham Univ. Press, Nottingham, UK.

Fisher, D. D., S. W. Saxton, R. D. Elliot, and J. M. Beatty. 1995 Effects of selenium source on Se status of lactating cows. Vet. Clin. Nutr. 2:68-74.

Fisher, L. J., C. Hoogendoorn, and J. Montemurro. 1980. The effect of added dietary selenium on the selenium content of milk, urine and feces. Can. J. Anim. Sci. 60:79-86.

Foltys, V., R. Bobcek, K. Kirchnerova, and I. Straka. 2004. Effect of Sel-Plex ${ }^{\mathrm{TM}}$ supplementation on milk selenium and somatic cell counts in a commercial dairy herd. Sel-Plex 317. Alltech Inc., Nicholasville, KY.

US Food and Drug Administration. 2003. Food additives permitted in feed and drinking water of animals: Selenium yeast. Fed. Regist. 68:52339-52340.

Fraser, A. J., T. J. Ryan, R. Sproule, R. G. Clark, D. Anderson, and E. O. Pederson. 1987. The effect of selenium supplementation on milk production in dairy cattle. Proc. N. Z. Soc. An. 47:61-64.

Furukawa, T. A., C. Barbui, A. Cipriani, P. Brambilla, and N. Watanabe. 2006. Imputing missing standard deviations in metaanalyses can provide accurate results. J. Clin. Epidemiol. 59:710.

Gierus, M. 2007. Organic and inorganic sources of selenium in the nutrition of dairy cows: Digestion, absorption, metabolism and requirements. Cienc. Rural 37:1212-1220.

Gierus, M., F. J. Schwarz, and M. Kirchgessner. 2002. Selenium supplementation and selenium status of dairy cows fed diets based on grass, grass silage or maize silage. J. Anim. Physiol. Anim. Nutr. (Berl.) 86:74-82.

Gierus, M., F. J. Schwarz, and M. Kirchgessner. 2003. Investigation on selenium supplementation for dairy cows in late pregnancy. Zuchtungskunde 75:88-100.

Givens, D. I., R. Allison, B. Cottrill, and J. S. Blake. 2004. Enhancing the selenium content of bovine milk through alteration of the form and concentration of selenium in the diet of the dairy cow. J. Sci. Food Agric. 84:811-817.

Goff, D. 2008. Dairy chemistry and physics. http://www.foodsci. uoguelph.ca/dairyedu/chem.html Accessed May 26, 2008.

Grace, N. D., K. L. Ankenbauer-Perkins, A. M. Alexander, and R. M. Marchant. 2001. Relationship between blood selenium concentration or glutathione peroxidase activity, and milk selenium concentrations in New Zealand dairy cows. N. Z. Vet. J. $49: 24-28$.

Grace, N. D., J. Lee, R. A. Mills, and A. F. Death. 1997. Influence of Se status on milk Se concentrations in dairy cows. N. Z. J. Agric. Res. 40:75-78

Grundler, M. 1999. Sel-Plex ${ }^{\mathrm{TM}}$ outperforms inorganic selenium in German dairy cattle and nursing calves. Sel-Plex 020. Alltech Inc., Nicholasville, KY.

Guyot, H., and F. Rollin. 2007. Diagnosis of selenium and iodine deficiencies in bovines. Ann. Med. Vet. 151:166-191.

Guyot, H., P. Spring, S. Andrieu, and F. Rollin. 2007. Comparative responses to sodium selenite and organic selenium supplements in Belgian Blue cows and calves. Livest. Sci. 111:259-263.

Harris, R. J., M. J. Bradburn, J. J. Deeks, R. M. Harbord, D. G Altman, and J. A. C. Sterne. 2008. metan: Fixed- and randomeffects meta-analysis. Stata J. 8:3-28.

Harrison, G. A., and S. A. Elliot. 2006. Influence of Sel-Plex ${ }^{\mathrm{TM}}$ supplementation on milk production, composition, and somatic cell count of lactating dairy cows in commercial dairy herds in Canada. 1. Whole herd responses. Sel-Plex 514. Alltech Inc., Lexington, $\mathrm{KY}$

Harrison, G. A., J. M. Tricarico, and S. A. Elliot. 2005a. Effect of Sel-Plex ${ }^{\mathrm{TM}}$ supplementation to lactating cows on blood and milk selenium levels in a commercial dairy herd in the southeastern US. Sel-Plex 409. Alltech Inc., Nicholasville, KY.

Harrison, G. A., J. M. Tricarico, and J. N. Tikofsky. 2005b. Effect of Sel-Plex ${ }^{\mathrm{TM}}$ supplementation to lactating dairy cows on blood and milk selenium in a commercial dairy herd in the northeastern US. Sel-Plex 407. Alltech Inc., Nicholasville, KY. 
Hartikainen, H. 2005. Biogeochemistry of selenium and its impact on food chain quality and human health. J. Trace Elem. Med. Biol. 18:309-318.

Hartikainen, H., and P. Ekholm. 2001. Selenium inclusion in fertilisers to correct an inadequate national dietary intake. Page 1 in Proc. Int. Fert. Soc., York, UK. Int. Fert. Soc., York, UK

Heard, J. W., C. R. Stockdale, G. P. Walker, C. M. Leddin, F. R. Dunshea, G. H. McIntosh, P. M. Shields, A. McKenna, G. P. Young, and P. T. Doyle. 2007. Increasing selenium concentration in milk: Effects of amount of selenium from yeast and cereal grain supplements. J. Dairy Sci. 90:4117-4127.

Heard, J. W., G. P. Walker, P. J. Royle, G. H. McIntosh, and P. T. Doyle. 2004. Effects of short-term supplementation with selenised yeast on milk production and composition of lactating cows. Aust. J. Dairy Technol. 59:199-203.

Hemken, R. W., R. J. Harmon, and S. Trammell. 1998. Selenium for dairy cattle: A role for organic selenium. Feed Compounder $18: 22-24$.

Hidiroglou, H., M. Ivan, and K. J. Jenkins. 1977. Influences of barley and oat silages for beef cows on occurrence of myopathy in their calves. J. Dairy Sci. 60:1905-1909.

Hidiroglou, M., A. J. McAllister, and C. J. Williams. 1987a. Prepartum supplementation of selenium and vitamin $\mathrm{E}$ to dairy cows: Assessment of selenium status and reproductive performance. J. Dairy Sci. 70:1281-1288.

Hidiroglou, M., and J. Proulx. 1988. Evaluation of a long-acting selenium and copper preparation for intraruminal administration to cattle. Ann. Rech. Vet. 19:187-191.

Hidiroglou, M., J. Proulx, and J. Jolette. 1985. Intraruminal selenium pellet for control of nutritional muscular dystrophy in cattle. J. Dairy Sci. 68:57-66.

Hidiroglou, M., J. Proulx, and J. Jolette. 1987b. Effect of intraruminally administered, selenium soluble-glass boluses on selenium status in cows and their calves. J. Anim. Sci. 65:815-820.

Higgins, J. P., S. G. Thompson, J. J. Deeks, and D. G. Altman. 2003. Measuring inconsistency in meta-analyses. BMJ 327:557-560.

Institute of Medicine. 2000. Dietary reference intakes for vitamin C, vitamin E, selenium, and carotenoids. Natl. Acad. Press, Washington, DC.

Ivancic, J. Jr., and W. P. Weiss. 2001. Effect of dietary sulfur and selenium concentrations on selenium balance of lactating Holstein cows. J. Dairy Sci. 84:225-232.

Jadad, A. R., D. J. Cook, and G. P. Browman. 1997. A guide to interpreting discordant systematic reviews. Can. Med. Assoc. J. 156:1411-1416.

Jadad, A. R., D. J. Cook, A. Jones, T. P. Klassen, P. Tugwell, M. Moher, and D. Moher. 1998. Methodology and reports of systematic reviews and meta-analyses: A comparison of Cochrane reviews with articles published in paper-based journals. JAMA 280:278-280.

Jenkins, K. J., M. Hidiroglou, J. M. Wauthy, and J. E. Proulx. 1974. Prevention of nutritional muscular dystrophy in calves and lambs by selenium and vitamin $\mathrm{E}$ additions to the maternal mineral supplement. Can. J. Anim. Sci. 54:49-60.

Judson, G. J., J. D. McFarlane, A. Mitsioulis, and P. Zviedrans. 1997. Vitamin $\mathrm{B}_{12}$ responses to cobalt pellets in beef cows. Aust. Vet. J. $75: 660-662$.

Juniper, D. T., R. H. Phipps, A. K. Jones, and G. Bertin. 2006 Selenium supplementation of lactating dairy cows: Effect on selenium concentration in blood, milk, urine, and feces. J. Dairy Sci. 89:3544-3551.

Kessler, J., and A. de Faria. 1998a. Organic trace element supplement in the nutrition of dairy cows. Agrarforschung 5:273-276.

Kessler, J., and A. de Faria. 1998b. The effect of an organic trace element supplement on metabolic parameters, milk yield and milk composition of dairy cows. Rev. Suisse Agric. 30:147-150.

Kincaid, R. L., and A. S. Hodgson. 1989. Relationship of selenium concentrations in blood of calves to blood selenium of the dam and supplemental selenium. J. Dairy Sci. 72:259-263.
Klawonn, W., K. Landfried, C. Muller, J. Kuhl, A. Salewski, and R. G. Hess. 1996. Effect of selenium on the health and metabolism of dairy cows. Tierarztl. Umsch. 51:411-417.

Knowles, S. O., N. D. Grace, T. W. Knight, W. C. McNabb, and J. Lee. 2004. Adding nutritional value to meat and milk from pasture-fed livestock. N. Z. Vet. J. 52:342-351.

Knowles, S. O., N. D. Grace, K. Wurms, and J. Lee. 1999. Significance of amount and form of dietary selenium on blood, milk, and casein selenium concentrations in grazing cows. J. Dairy Sci. 82:429437.

Kohler, P., E. Farries, M. Anke, D. Smidt, and H. P. Sallmann. 1994. Influence of additional selenium supply on performance and metabolic indicators in dairy cows at pasture. Zuchtungskunde 66:66-72.

Koller, L. D., G. A. Whitbeck, and P. J. South. 1984. Transplacental transfer and colostral concentrations of selenium in beef cattle. Am. J. Vet. Res. 45:2507-2510.

Lacetera, N., U. Bernabucci, B. Ronchi, and A. Nardone. 1996. Effects of selenium and vitamin $\mathrm{E}$ administration during a late stage of pregnancy on colostrum and milk production in dairy cows, and on passive immunity and growth of their offspring. Am. J. Vet. Res. 57:1776-1780.

Lau, J., C. H. Schmid, and T. C. Chalmers. 1995. Cumulative metaanalysis of clinical trials builds evidence for exemplary medical care. J. Clin. Epidemiol. 48:45-57.

Lein, D. H., G. A. Maylin, D. G. Braund, W. H. Gutenmann, L. E. Chase, and D. J. Lisk. 1980. Increasing selenium in bovine blood by feed supplements or selenium injections. Cornell Vet. 70:113-124.

Lewis, T. 2004. Effect of feeding additional Sel-Plex ${ }^{\mathrm{TM}}$ on selenium levels in cow colostrum. Sel-Plex 318. Alltech Inc., Nicholasville, $\mathrm{KY}$

Little, W., M. J. Vagg, K. A. Collis, S. R. Shaw, and P. T. Gleed. 1979. The effects of subcutaneous injections of sodium selenate on blood composition and milk yield in dairy cows. Res. Vet. Sci. 26:193-197.

Malbe, M., E. Klaassen, L. Kaartinen, M. Attila, and F. Atroshi. 2003. Effects of oral selenium supplementation on mastitis markers and pathogens in Estonian cows. Vet. Ther. 4:145-154.

Malbe, M., M. Klaassen, W. Fang, V. Myllys, M. Vikerpuur, K. Nyholm, S. Sankari, K. Suoranta, and M. Sandholm. 1995. Comparisons of selenite and selenium yeast feed supplements on Se-incorporation, mastitis and leucocyte function in Se-deficient dairy cows. Zbl. Vet. Med. A 42:111-121.

Maus, R. W., F. A. Martz, R. L. Belyea, and M. F. Weiss. 1978. Effect of dietary selenium on selenium in blood and milk of dairy cows. J. Dairy Sci. 61(Suppl. 1):181.

Maus, R. W., F. A. Martz, R. L. Belyea, and M. F. Weiss. 1980. Relationship of dietary selenium to selenium in plasma and milk from dairy cows. J. Dairy Sci. 63:532-537.

McDowell, L. R. 2002. Recent advances in minerals and vitamins on nutrition of lactating cows. Pak. J. Nutr. 1:8-19.

McDowell, L. R., G. Valle, L. Cristaldi, P. A. Davis, O. Rosendo, and N. S. Wilkinson. 2002. Selenium availability and methods of selenium supplementation for grazing ruminants. Page 86 in Proc. 13th Annu. Florida Rumin. Nutr. Symp., Gainesville, FL. Univ. Florida, Gainesville.

McIntosh, G. H., and P. J. Royle. 2002. Supplementation of cows with organic selenium and the identification of selenium-rich protein fractions in milk. Pages 233-238 in Biotechnology in the Feed Industry: Proc. Alltech's 18th Annu. Symp. T. P. Lyons, and K. A. Jacques, ed. Nottingham Univ. Press, Nottingham, UK.

Meglia, G. E., A. Johannisson, L. Petersson, and K. P. Waller. 2001. Changes in some blood micronutrients, leukocytes and neutrophil expression of adhesion molecules in periparturient dairy cows. Acta Vet. Scand. 42:139-150

Moher, D., B. Pham, A. Jones, D. J. Cook, A. R. Jadad, M. Moher, P. Tugwell, and T. P. Klassen. 1998. Does quality of reports of randomised trials affect estimates of intervention efficacy reported in meta-analyses? Lancet 352:609-613. 
Moxon, A. L., and D. L. Palmquist. 1980. Selenium content of foods grown or sold in Ohio. Ohio Rep. Res. Dev. 65:13-14.

Muniz-Naveiro, O., R. Dominguez-Gonzalez, A. Bermejo-Barrera, P. Bermejo-Barrera, J. A. Cocho, and J. M. Fraga. 2006. Study of the bioavailability of selenium in cows' milk after a supplementation of cow feed with different forms of selenium. Anal. Bioanal. Chem. 385:189-196.

Muniz-Naveiro, O., R. Dominguez-Gonzalez, A. Bermejo-Barrera, P. Bermejo-Barrera, J. A. Cocho, and J. M. Fraga. 2007. Selenium speciation in cow milk obtained after supplementation with different selenium forms to the cow feed using liquid chromatography coupled with hydride generation-atomic fluorescence spectrometry. Talanta 71:1587-1593.

Muniz-Naveiro, O., R. Dominguez-Gonzalez, A. Bermejo-Barrera, J. A. Cocho de Juan, J. M. Fraga-Bermudez, A. Goris-Pereiras, A. Lopez-Santamarina, I. Martinez-Lede, J. Valledor-Puente, L. Fernandez-Couto-Gomez, and P. Bermejo-Barrera. 2005. Selenium content and distribution in cow's milk supplemented with two dietary selenium sources. J. Agric. Food Chem. 53:9817-9822.

NRC. 2000. Nutrient Requirements of Beef Cattle. 7th rev. ed. Natl. Acad. Press, Washington, DC.

NRC. 2001. Nutrient Requirements of Dairy Cattle. 7th rev. ed. Natl. Acad. Press, Washington, DC.

Nicholson, J. W. G., A. M. St Laurent, R. E. McQueen, and E. Charmley. 1990. The effect of feeding organically bound selenium and tocopherol to dairy cows on susceptibility of milk to oxidation. J. Dairy Sci. 73(Suppl. 1):285.

Oldfield, J. E. 2002. Selenium World Atlas. Selenium-Tellurium Dev. Assoc., Grimbergen, Belgium.

Ortman, K., and B. Pehrson. 1997. Selenite and selenium yeast as feed supplements for dairy cows. Zentralbl. Veterinarmed. A 44:373380.

Ortman, K., and B. Pehrson. 1999. Effect of selenate as a feed supplement to dairy cows in comparison to selenite and selenium yeast. J. Anim. Sci. 77:3365-3370.

Paschoal, J. J., M. A. Zanetti, G. R. Del Claro, M. P. de Melo, S. P. Pugine, and J. A. Cunha. 2007. Fatty acid profile and oxidative stability of milk from Holstein cows fed with extruded soybean and organic selenium. Pesquisa Agropecu. Bras. 42:1793-1799.

Paula-Lopes, F. F., Y. M. Al Katanani, A. C. Majewski, L. R. McDowell, and P. J. Hansen. 2003. Manipulation of antioxidant status fails to improve fertility of lactating cows or survival of heat-shocked embryos. J. Dairy Sci. 86:2343-2351.

Pavlata, L., J. Prasek, J. Filipek, and A. Pechova. 2004. Influence of parenteral administration of selenium and vitamin $\mathrm{E}$ during pregnancy on selected metabolic parameters and colostrum quality in dairy cows at parturition. Vet. Med. Czech. 49:149-155.

Pavlata, L., J. Prasek, A. Podhorsky, A. Pechova, and T. Haloun. 2003. Selenium metabolism in cattle: Maternal transfer of selenium to newborn calves at different selenium concentrations in dams. Acta Vet. (Brno) 72:639-646.

Pehrson, B. 2005. Organic selenium for supplementation of farm animal diets: Its influence on the selenium status of the animals and on the dietary selenium intake of man. Pages 253-267 in Re-defining Mineral Nutrition. J. A. Taylor-Pickard, and L. A. Tucker, ed. Nottingham Univ. Press, Nottingham, UK.

Pehrson, B., and F. A. Arnesson. 2003. Selenium in milk after supplementation of inorganic and organic selenium to dairy cows in ecological herds. Sven. Vet. Tidn. 55:17-23.

Pehrson, B., and S. Johnsson. 1985. The effect of single, peroral doses of selenium in beef cows and suckling calves. Zbl. Vet. Med. A 32:433-436.

Pehrson, B., K. Ling, and K. Ortman. 1997. The selenium status of dairy cattle in Estonia. Acta Vet. Scand. 38:353-356.

Pehrson, B., and K. Ortman. 1995. A comparative study of selenite and selenium yeast (Sel-Plex ${ }^{\mathrm{TM}} 50$ ) as feed supplements for multiparous dairy cows. Pages 283-286 in Biotechnology in the Feed Industry: Proc. Alltech's 11th Annu. Symp. T. P. Lyons, and K. A. Jacques, ed. Nottingham Univ. Press, Nottingham, UK.

Pehrson, B., K. Ortman, N. Madjid, and U. Trafikowska. 1999. The influence of dietary selenium as selenium yeast or sodium selenite on the concentration of selenium in the milk of suckler cows and on the selenium status of their calves. J. Anim. Sci. 77:3371-3376.

Perry, T. W., R. C. Peterson, and W. M. Beeson. 1977. Selenium in milk from feeding small supplements. J. Dairy Sci. 60:16981700.

Phipps, R. H., A. S. Grandison, A. K. Jones, D. T. Juniper, and G. Bertin. 2007. Selenium supplementation of lactating dairy cows: Effects on total selenium content and speciation in blood, milk, and cheese. J. Dairy Sci. 90(Suppl. 1):599.

Salih, Y., L. R. McDowell, J. F. Hentges, R. M. Mason Jr., and C. J. Wilcox. 1987. Mineral content of milk, colostrum and serum as affected by physiological state and mineral supplementation. J. Dairy Sci. 70:608-612.

Sargeant, J. M., A. Rajic, S. Read, and A. Ohlsson. 2006. The process of systematic review and its application in agri-food public-health. Prev. Vet. Med. 75:141-151.

Schingoethe, D. J., C. A. Kirkbride, I. S. Palmer, M. J. Owens, and W. L. Tucker. 1982. Response of cows consuming adequate selenium to vitamin E and selenium supplementation prepartum. J. Dairy Sci. 65:2338-2344.

Serdaru, M., L. Vladescu, and I. Tolea. 2004. Fluorimetric study of the selenium course in the dam-calf relationship. Biol. Trace Elem. Res. 99:113-122.

Shen, L., K. van Dyck, J. Luten, and H. Deelstra. 1997. Diffusibility of selenate, selenite, seleno-methionine, and seleno-cystine during simulated gastrointestinal digestion. Biol. Trace Elem. Res. 58:55-63.

Stagsted, J., T. Hoac, B. Akesson, and J. H. Nielsen. 2005. Dietary supplementation with organic selenium (Sel-Plex ${ }^{\mathrm{TM}}$ ) alters oxidation in raw and pasteurised milk. Pages 249-257 in Biotechnology in the Feed Industry: Proc. Alltech's 21st Annu. Symp. T. P. Lyons, and K. A. Jacques, ed. Nottingham Univ. Press, Nottingham, UK.

Sterne, J. A., M. Egger, and G. D. Smith. 2001. Investigating and dealing with publication and other biases. Pages 189-208 in Systematic Reviews in Health Care: Meta-analysis in Context. M. Egger, G. D. Smith, and D. G. Altman, ed. BMJ Books, London, UK.

Stowe, H. D., J. W. Thomas, T. Johnson, J. V. Marteniuk, D. A Morrow, and D. E. Ullrey. 1988. Responses of dairy cattle to longterm and short-term supplementation with oral selenium and vitamin E. J. Dairy Sci. 71:1830-1839.

Sustala, M., J. Trinacty, J. Illek, V. Kudrna, and K. Sustova. 2003. Effects of short-term supplementation of dairy cow diets with surplus selenium and rapeseed meal on milk and blood selenium levels. Czech J. Anim. Sci. 48:223-231.

Sutton, A. J., K. R. Abrams, D. R. Jones, T. A. Sheldon, and F. Song. 2000. Methods for Meta-analysis in Medical Research. John Wiley and Sons Ltd., Chichester, UK.

Symonds, H. W., B. F. Sansom, D. L. Mather, and M. J. Vagg. 1981 Selenium metabolism in the dairy cow: The influence of the liver and the effect of the form of Se salt. Br. J. Nutr. 45:117-125.

Syrjala Qvist, L., and P. Aspila. 1993. Selenium fertilization in Finland: Effect on milk and beef production. Nor. J. Agric. Sci. 11:159-167.

Tasker, J. B., T. D. Bewick, R. G. Clark, and A. J. Fraser. 1987. Selenium response in dairy cattle. N. Z. Vet. J. 35:139-140.

Ullrey, D. E. 1992. Basis for regulation of selenium supplements in animal diets. J. Anim. Sci. 70:3922-3927.

Waldron, M. R., T. L. Ward, M. T. Socha, and T. R. Overton. 2004. Tissue selenium content and whole-blood glutathione peroxidase activity of lactating cows are increased by two organic forms of dietary selenium. J. Dairy Sci. 87(Suppl. 1):118.

Walker, G. P., P. T. Doyle, and F. R. Dunshea. 2004. Milk selenium concentration varies with time of year and feeding practices in grazing cows. Asia Pac. J. Clin. Nutr. 13(Suppl.):S84.

Weiss, W. P. 2005. Selenium sources for dairy cattle. Page 61 in Proc. Tri-State Dairy Nutr. Conf., Fort Wayne, IN. The Ohio State University, Columbus.

Weiss, W. P., and J. S. Hogan. 2005. Effect of selenium source on selenium status, neutrophil function, and response to intramammary endotoxin challenge of dairy cows. J. Dairy Sci. 88:4366-4374. 
Wichtel, J. J., G. P. Keefe, J. A. Van Leeuwen, E. Spangler, M. A. McNiven, and T. H. Ogilvie. 2004. The selenium status of dairy herds in Prince Edward Island. Can. Vet. J. 45:124-132.

Wiewiora, W., F. Brzoska, and B. Brzoska. 2003. Effect of selenium in daily ration on cows' yield and selenium concentration in milk and blood. Ann. Anim. Sci. 3:67-79.

Wiewiora, W., F. Brzoska, B. Brzoska, and M. Pietras. 2004. Iodine and selenium concentration in cows' milk and plasma and its relation to milk yield, mineral content and selected metabolic parameters. Ann. Anim. Sci. 4:79-90.
World Health Organization/Food and Agriculture Organization of the United Nations. 2004. Vitamin and mineral requirements in human nutrition: Report of a joint FAO/WHO expert consultation. Marketing and Dissemination of WHO/FAO of the United Nations, Geneva, Switzerland.

Zarski, T. P., and B. Debski. 1996. A comparison of effectiveness of the oral and parenteral form of selenium supplementation in Sedeficient dairy cows. Ann. Warsaw Agricult. Univ. Anim. Sci. $32: 71-78$.

\section{APPENDIX}

Table A1. List of references excluded from the analysis

\begin{tabular}{|c|c|}
\hline Reason for exclusion & Reference \\
\hline Not clinical trials & $\begin{array}{l}\text { Conrad and Moxon (1980) } \\
\text { Moxon and Palmquist (1980) } \\
\text { Symonds et al. (1981) } \\
\text { Binnerts et al. (1984) } \\
\text { Ekholm et al. (1991) } \\
\text { Pehrson and Ortman (1995) } \\
\text { Pehrson et al. (1997) } \\
\text { McDowell (2002) } \\
\text { Serdaru et al. (2004) } \\
\text { Walker et al. (2004) } \\
\text { Pehrson (2005) } \\
\text { Weiss (2005) }\end{array}$ \\
\hline Did not report the outcome of interest & $\begin{array}{l}\text { Dell (1974) } \\
\text { Hidiroglou et al. (1977) } \\
\text { Lein et al. (1980) } \\
\text { Pehrson and Johnsson (1985) } \\
\text { Fraser et al. (1987) } \\
\text { Tasker et al. (1987) } \\
\text { Kincaid and Hodgson (1989) } \\
\text { Eversole et al. (1992) } \\
\text { Coe et al. (1993) } \\
\text { Kohler et al. (1994) } \\
\text { Charlton (1995) } \\
\text { Klawonn et al. (1996) } \\
\text { Lacetera et al. (1996) } \\
\text { Culleton et al. (1997) } \\
\text { Judson et al. (1997) } \\
\text { Acevedo-Maldonado et al. (1999) } \\
\text { Enjalbert et al. (1999) } \\
\text { Falkowska et al. (2000) } \\
\text { Meglia et al. (2001) } \\
\text { Malbe et al. (2003) } \\
\text { Paula-Lopes et al. (2003) } \\
\text { Lewis (2004) } \\
\text { Fan et al. (2006) } \\
\text { Harrison and Elliot (2006) }\end{array}$ \\
\hline
\end{tabular}

Continued 
Table A1 (Continued). List of references excluded from the analysis

\begin{tabular}{|c|c|}
\hline Reason for exclusion & Reference \\
\hline Reported duplicate data from other studies & $\begin{array}{l}\text { Maus et al. (1978) } \\
\text { Nicholson et al. (1990) } \\
\text { Cuesta (1992) } \\
\text { Fisher (1995) } \\
\text { Fisher et al. (1995) } \\
\text { Kessler and de Faria (1998a) } \\
\text { Muniz-Naveiro et al. (2006) } \\
\text { Muniz-Naveiro et al. (2007) } \\
\text { Pehrson and Ortman (1995) }\end{array}$ \\
\hline Described results of parenteral Se supplementation & $\begin{array}{l}\text { Little et al. (1979) } \\
\text { Schingoethe et al. (1982) } \\
\text { De Toledo and Perry (1985) } \\
\text { Hidiroglou et al. (1987a) } \\
\text { Culleton et al. (1993) } \\
\text { Cuesta et al. (1994) } \\
\text { Zarski and Debski (1996) } \\
\text { Grace et al. (1997) } \\
\text { McDowell et al. (2002) } \\
\text { Pavlata et al. (2003) } \\
\text { Pavlata et al. (2004) }\end{array}$ \\
\hline Control group was not unsupplemented & $\begin{array}{l}\text { Maus et al. (1980) } \\
\text { Essick and Lisk (1987) } \\
\text { Fisher et al. (1995) } \\
\text { Ortman and Pehrson (1997) } \\
\text { Awadeh et al. (1998) } \\
\text { Kessler and de Faria (1998b) } \\
\text { Grundler (1999) } \\
\text { Pehrson et al. (1999) } \\
\text { Ivancic and Weiss (2001) } \\
\text { Pehrson and Arnesson (2003) } \\
\text { Brzoska (2004) } \\
\text { Foltys et al. (2004) } \\
\text { Givens et al. (2004) } \\
\text { Lewis (2004) } \\
\text { Diaz et al. (2005) } \\
\text { Harrison et al. (2005a,b) } \\
\text { Weiss and Hogan (2005) } \\
\text { Wiewiora et al. (2004) }\end{array}$ \\
\hline Two sources of Se given to the same animal & Koller et al. (1984) \\
\hline Two routes of Se administration to the same animal & Salih et al. (1987) \\
\hline
\end{tabular}

